Technical Note

\title{
Analysis of Basic Physical-Chemical Parameters, Nutrients and Heavy Metals Content in Surface Water of Small Catchment Area of Karašica and Vučica Rivers in Croatia
}

\author{
Ana Amić ${ }^{1, *}$ and Lidija Tadić ${ }^{2}$ \\ 1 Department of Chemistry, Josip Juraj Strossmayer University of Osijek, 31000 Osijek, Croatia \\ 2 Faculty of Civil Engineering, Josip Juraj Strossmayer University of Osijek, 31000 Osijek, Croatia; \\ ltadic@gfos.hr \\ * Correspondence: aamic@kemija.unios.hr; Tel.: +385-31-399-980
}

Received: 19 December 2017; Accepted: 25 January 2018; Published: 27 January 2018

\begin{abstract}
This paper deals with the surface water quality of a small catchment area of the Karašica and Vučica rivers based on the analysis of water physical and chemical parameters according to the national Decree on Water Quality Standards (2013). Water samples were collected and analysed monthly at five sampling stations situated along the watercourses in the period between 1998 and 2015. Analysed parameters were $\mathrm{pH}$, chemical oxygen demand (COD-Mn), five-day biochemical oxygen demand $\left(\mathrm{BOD}_{5}\right)$, nutrients: nitrate compounds (nitrates and total nitrogen), phosphorus compounds (orthophosphates and total phosphorus), and the content of heavy metals. The obtained results indicate a water quality status between moderate and good, depending on the parameter and sampling station.
\end{abstract}

Keywords: small catchment area; water quality; nutrients; $\mathrm{COD}-\mathrm{Mn}$; $\mathrm{BOD}_{5}$; heavy metals

\section{Introduction}

Intensive agriculture causes dispersive pollution of soil and water which may have a significant influence on the environment in general [1]. In fact, application of mineral fertilizers, especially nitrate-based fertilizers, contributes to yield increase, but at the same time endangers the environment. Over the years, numerous research studies have proved that the majority of the areas with intensive agriculture are exposed to the soil and water pollution. The world's most productive agriculture is on artificially drained soils, drainage is increasingly perceived as a major contributor to detrimental off-site environmental impacts [2]. The quantity of nitrogen applied to the soil is often much larger than the quantity the crop can use [3]. Oxidation processes of burned-in nitrogen result with nitrates that often end up in nearby watercourses causing eutrophication of the aquatic ecosystems [4]. The larger the quantity of the unused applied nitrogen, the larger the threat to the surface and ground water. Artificial subsurface drainage is the major pathway for nitrate loss from subsurface-drained agricultural lands. All else being equal, installation of subsurface drainage results in greater leaching of nitrate from the soil profile than prior to drainage by shifting the major pathway for excess precipitation [5]. In addition, time of fertilizing, quantity and type of fertilizers, soil type (sandy soil has higher nutrient losses than loam and clay soils), precipitation, crop, are all factors of complex processes in the soil-water-plant system [6]. Higher concentration of nutrients in the potable water can cause many serious diseases of the respiratory system [7], reproductive problems [8,9], methemoglobinemia [9,10], and some types of cancer [11,12]. High concentrations of nitrites are toxic for the plants too, causing yield reduction and leaf chlorosis. Furthermore, if phenols and anaerobic conditions are present, it could produce 
toxic nitrophenols, especially in acidic soils after application of nitrogen fertilizers during wet and cold weather [13].

The aim of this paper is to assess water pollution caused by nonpoint sources. Other important contributors to organic and nutrient parameters are municipal and industrial effluents. In other words, the main causes of water pollution are anthropogenic activities which contribute not only to organic and nutrient parameters, but to $\mathrm{Pb}, \mathrm{Zn}$ and $\mathrm{Cd}$ concentrations as well [14,15]. Nutrients are just one group of pollutants which endanger water and the environment in general. Besides them, the most important parameters in assessing variations of river water quality are alkalinity/acidity, salinity, Mg, $\mathrm{Ca}$, dissolved organic carbon (DOC) and total organic carbon (TOC) [16].

Water quality is highly related to general environmental status of any area, as elaborated in many scientific publications. However, water quality can be analysed from the economic point of view. Implementation of different water quality improving measures generates significant costs, such as subvention of agricultural production, and implementation of new environmentally safe production methods, construction of wastewater treatment plants, etc. Consequently, large rivers usually have priority in the implementation of the protection measures. Many studies show an increase of metal and bacterial concentrations in the river water, and should be considered as a warning and incentive to protect the small and medium size rivers from future deterioration, as recommended by EU Water Framework Directive [17]. Since the majority of the aforesaid observations refer to large rivers, in the present study we have chosen two small- to medium-size rivers (Karašica and Vučica) to investigate the impact of the increased agricultural land use and longer-term contamination on the water quality.

In the last 30 years, water of the Karašica and Vučica rivers has been a subject of interest to a few researchers. Munjko et al. (1980) were investigating the content of eutrophic salts in the water of those rivers during the period between 1972 and 1980. Their results indicated mostly satisfactory water quality with the occasional pollution caused by the distaff industry. Downstream of the town Valpovo, the Karašica River water had significant organic and inorganic pollution. Chemical oxygen demand (COD) was between 5 and $105 \mathrm{mgO}_{2} / \mathrm{L}$ and biological oxygen demand (BOD) between 1.4 and $26 \mathrm{mgO}_{2} / \mathrm{L}$. The Vučica River had mild alkaline water ( $\mathrm{pH}$ between 7.4 and 8.1), COD was 6-22 $\mathrm{mgO}_{2} / \mathrm{L}, \mathrm{BOD}_{5}$ was 3-7 mgO $/ 2$ L and concentration of phosphates was increased [18].

Vidaček et al. (1999) were researching concentration of nitrates, heavy metals and herbicides in the soil, surface and groundwater during 1997 and 1998. Nitrate concentrations varied depending on fertilizing intensity, precipitation, drainage functioning and nitrate crop consumption, and were found to be between 0.56 and $5.06 \mathrm{mg} \mathrm{NO}_{3}^{-} / 100 \mathrm{~g}$ of soil and regularly higher on the plots of land with more intensive application of nitrogen fertilizers. Nitrate concentrations in the analysed samples of surface and groundwater occasionally exceeded maximum allowed concentrations, with the highest obtained value of $126 \mathrm{mg} \mathrm{NO}_{3}{ }^{-} / \mathrm{L}$ [19]. To illustrate the difference, in the Drava River, which belongs to the group of large rivers, this parameter is less than $3.0 \mathrm{mg} \mathrm{NO}_{3}{ }^{-} / \mathrm{L}$ [20]. Motivated by the fact that agriculture is a wide-spread activity in the study area, the aim of this paper is to analyse physical and chemical water quality parameters in the last 15 years and to determine whether the water quality has changed or not.

\section{Study Area}

The catchment area of the Karašica and Vučica rivers is situated in the north-east part of Croatia. Both rivers have their sources in the hilly part of the catchment. Upstream of the Vučica-Drava confluence, the Karašica River flows into the Vučica River. The total catchment area is $2.352 \mathrm{~km}^{2}$ and more than half of the total area is agricultural land $\left(1.420 \mathrm{~km}^{2}\right)$ (Figure 1). The catchment comprises a complex network of drainage canals and other hydro-technical structures [21,22]. According to the Water Framework Directive, the Vučica River is classified as a small river with clay-sand bottom (HR-R_2A) and the Karašica River belongs to the group of medium and large rivers (HR-R_4) [21]. Water quality data used in this paper has been collected at five monitoring stations, listed in Table 1. 


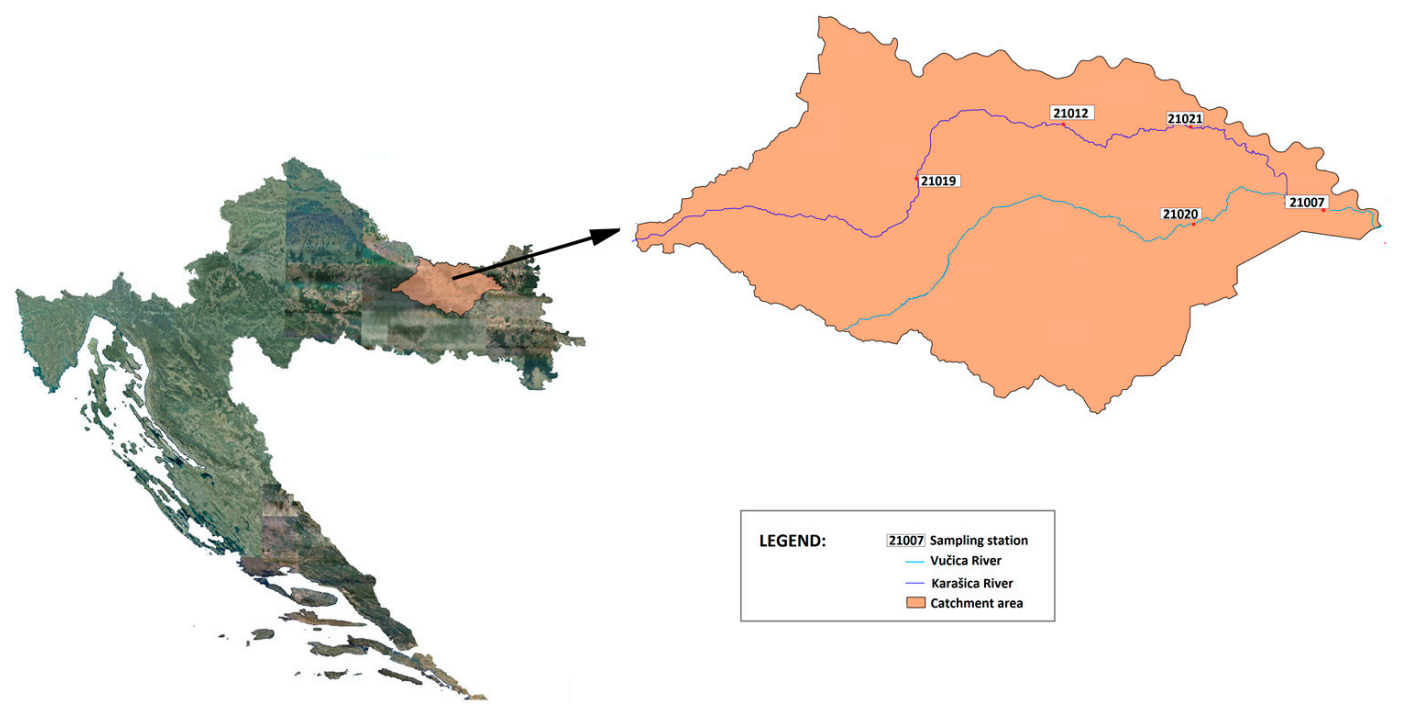

Figure 1. Study area with designated locations of water quality monitoring stations.

Table 1. Water quality monitoring (sampling) stations in the Karašica-Vučica rivers catchment area sorted from the most upstream to the most downstream station.

\begin{tabular}{ccc}
\hline & Karašica River & \\
\hline Sampling station & Station code & Analysed years \\
\hline Road Crnac-Krčenik & 21019 & $2000-2003,2012-2015$ \\
Črnkovci & 21012 & $1998-2015$ \\
Downstream of Valpovo & 21021 & $1998,1999,2012,2013,2015$ \\
\hline & Vučica River & \\
\hline Sampling station & Station code & 1998, 1999, 2012-2015 \\
\hline Marjančaci & 21020 & $1998-2015$ \\
\hline
\end{tabular}

* Data for 2004 are not available.

The vegetation cover consists of arable land, pastures, forest and orchards. Soil types consist mainly of clay and loam. Heavy clay with very low hydraulic conductivity soil covers about $70 \%$ of the area reducing groundwater contamination [23], and is very important due to the fact that agriculture is a dominant activity and a potential threat to the surface and groundwater quality. Other pollution sources are the paper, cement and wood industries.

\section{Materials and Methods}

The basic physical and chemical water quality parameters are defined in the Decree on Water Quality Standards and its additions [24,25]. Water samples were taken and analysed on a monthly basis (as recommended by the Decree) during the period between 1998 and 2015 at five sampling stations. Three sampling stations are on the Karašica River, and two stations are on the Vučica River, one of which is after their confluence (Figure 1). There are no sampling stations on the upper part of the Vučica River, due to the lack of the potential pollution sources-land cover is mainly forest, inhabitants are scarce, there are no industrial facilities. Some of these water quality sampling stations have shorter data records (Table 1). Physical and chemical parameters analysed in this paper are: water acidity $(\mathrm{pH})$, chemical oxygen demand (COD-Mn), five-day biochemical oxygen demand $\left(\mathrm{BOD}_{5}\right)$ and nutrients-nitrogen (nitrates, total nitrogen) and phosphorus (orthophosphates, total phosphorus). Samples were analysed immediately after sampling by using the following methods: $\mathrm{pH}$-method 
HRN ISO 10523:2009; COD-Mn—method HR EN ISO 8467:2001; BOD $_{5}$-method HRN EN ISO 5815:1998; nitrate concentrations-method HRN ISO 780-3:1998; total nitrogen-method ISO/TR 11905-2:1997; total phosphorus—method HRN ISO 6878:2001; phosphate concentration-method HRN EN ISO 6878:2008. Heavy metals concentrations (copper, zinc, cadmium, chromium, nickel, manganese, mercury, arsenic, lead and iron) were analysed by using the method HRN ISO 17294-2:2003. Implementation of previously listed international standards ensures valid procedures, accuracy and precision.

For sampling stations 21007 and 21012, data records of heavy metals concentration are available for a six-year period (2010-2015) and for stations 21020 and 21021, data for two more years, 1998 and 1999, are available. According to current Croatian regulations, the surface water status is determined based on the value of the 50th percentile of the heavy metals concentration, physical and chemical parameters.

Recommended sampling frequency for water quality monitoring is on a regular monthly basis. This can cause monitoring imprecision due to the possibility of sampling in extreme situations, such as extremely low discharges or sampling too soon after the application of fertilizers, especially in the period of heavy precipitation when leaching through the soil profile is great. In these cases, incorrect results can show much higher concentration of analysed parameters and lead to wrong conclusions. However, more frequent sampling requires additional financial resources.

\section{Results and Discussion}

The Decree on Water Quality Standards (Official Gazette 73/13) based on the limiting value of the 50th percentile of selected physical and chemical parameters defines two categories of ecological condition of water (very good and good), as well as limiting values of eutrophication indicators for each condition. Furthermore, the exact limiting values for every parameter have been separately determined for every ecoregion and type of surface water.

\subsection{Water Acidity}

Water acidity $(\mathrm{pH})$ influences the majority of chemical reactions that take place in aquatic medium, and determines the structure of aquatic biological communities (plants, animals, microorganisms). The $\mathrm{pH}$ value of the majority of lakes and various types of running water is in the range from 6.5 to 8.5 , while a $\mathrm{pH}$ below 4 or above 10 generally creates unfavourable living conditions in aquatic systems [26]. The Decree (Official Gazette 73/13) defines as limiting value of the 50th percentile for very good water quality of both rivers a $\mathrm{pH}$ range of 7.4-8.5, and for good quality ranges of 7.0-7.4 and 8.5-9.

The lowest value of the 50th percentile of the $\mathrm{pH}$ of surface water of the Karašica River was observed in the year 2000 at sampling station 21019 (7.31), while the highest value was observed in 1999 at sampling station 21021 (9.2) (Figure 2) (Appendix A, Table A1). This was also the only determined $\mathrm{pH}$ value that exceeded the upper limit of good ecological condition. The lowest value of the 50th percentile of the $\mathrm{pH}$ of surface water of the Vučica River was measured in 1999 at sampling station 21007 (7.4), while the highest value was determined to be 7.9 and was observed during several years at both sampling stations-in 1998 and 2015 at sampling station 21020, and in 2013 at sampling station 21007 (Appendix A, Table A2).

Considering determined values of the 50th percentile for $\mathrm{pH}$ of surface water, it can be concluded that surface waters of the Karašica-Vučica catchment area are good quality waters, except at sampling station 21007 , where the water quality is classified as very good. The only occasion when the determined $\mathrm{pH}$ value of the Karašica River surface water exceeded the upper value of good quality was in 1999 (9.2). During the analysed period, such a situation was not observed in the Vučica River surface water. According to the 50th percentile, surface water of the Vučica River can be characterised as slightly alkaline, which was also the case in the period from 1972 until 1980 [18]. Surface water of the Karašica River is also slightly alkaline, with a pH range of 7.31-9.2. 


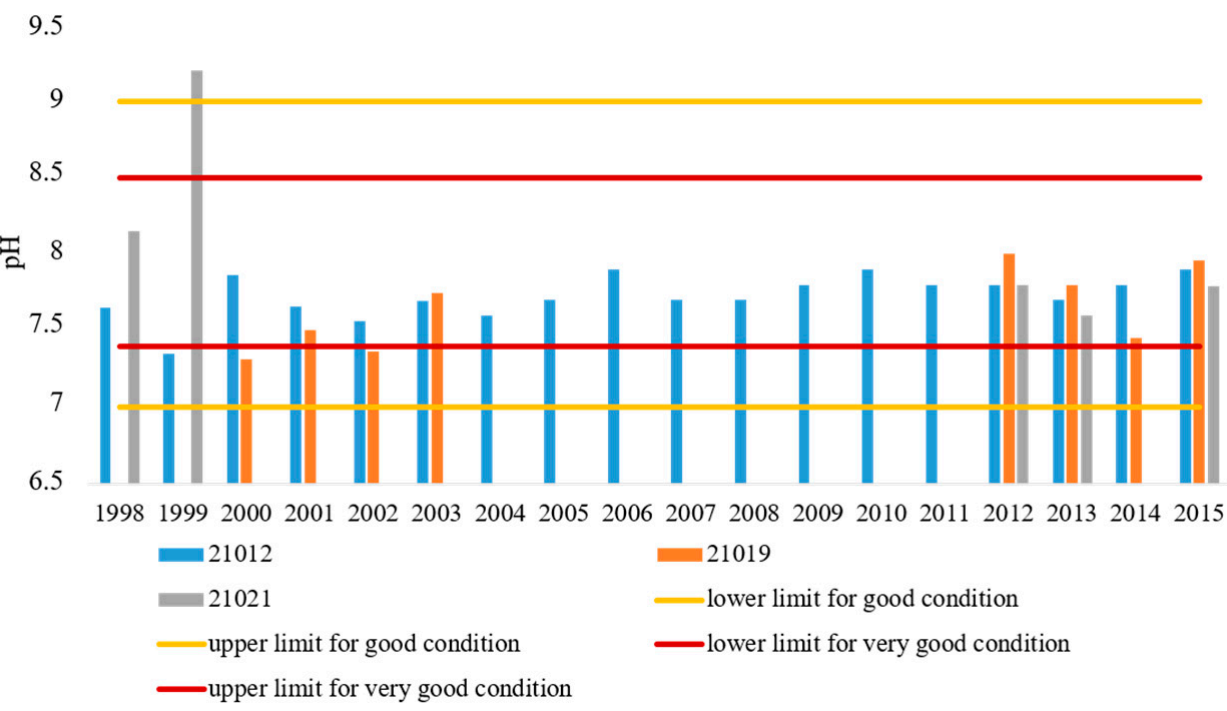

B

9.5

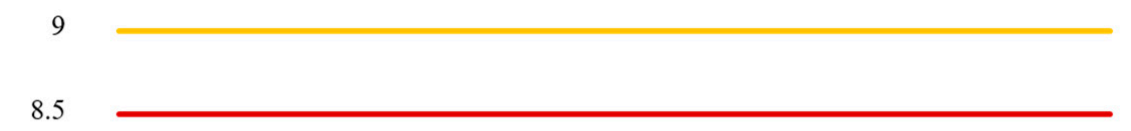

客 8

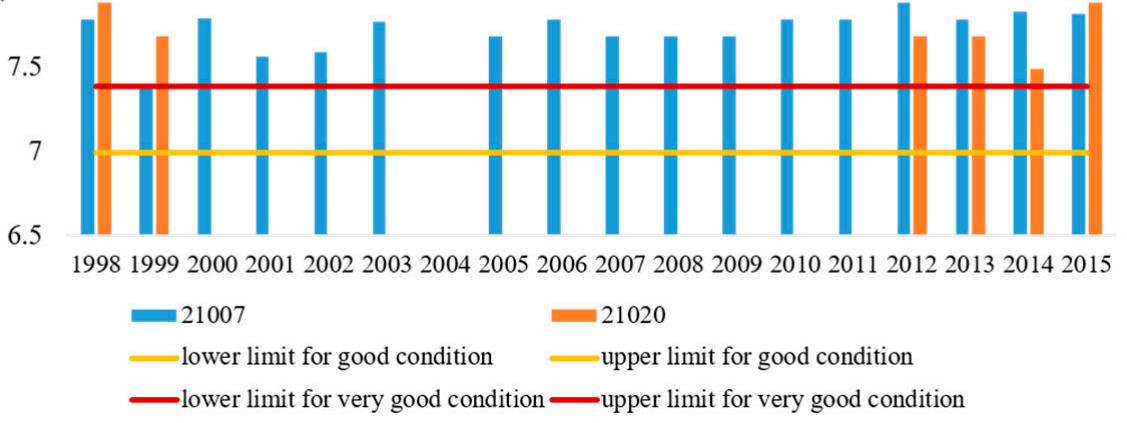

Figure 2. Acidity (pH) of surface waters of the (A) Karašica and (B) Vučica Rivers form 1998 until 2015.

A 24-year survey of surface water quality data of the Drava River in eastern Croatia was conducted by Gvozdić et al. (2012). This research is interesting, due to the fact that the Karašica-Vučica river flows into the Drava River. One of the analysed parameters was water acidity. Observed $\mathrm{pH}$ values were similar to the ones presented in our paper, and were ranging from 6.9 to 9.6 , with median value of 7.8, respectively. Due to the presence of carbonates and bicarbonates, the $\mathrm{pH}$ of water samples of analysed catchment and of the Drava River are slightly alkaline [27].

Water acidity was analysed by Abu and Egenonu (2008) in the monitoring study conducted within the New Calabar River in the Niger Delta region of Southern Nigeria, which is in the vicinity of the Port Harcourt city. Mean values were slightly acidic, and ranged from 5 to 6, which was linked to effluent discharge from industries sited along the river banks [28]. Similar results were reported by Eisakhani and Malakahmad (2009) who analysed $\mathrm{pH}$ values in the surface water of the Bertam River and its tributaries in Cameron Highlands, in Malaysia. The $\mathrm{pH}$ was found to be slightly acidic (6.32-7.08, respectively) [29], probably due to its origin of rain water, and due to tannin and leave acids released from the forest floors [30]. 


\subsection{Water Oxygenation Demand}

Water oxygenation demand is an important parameter for the determination of the quality of any given body of water, and it includes chemical oxygen demand (COD-Mn, $\mathrm{mg} \mathrm{O}_{2} / \mathrm{L}$ ) and five-day biochemical oxygen demand $\left(\mathrm{BOD}_{5}, \mathrm{mg} \mathrm{O}_{2} / \mathrm{L}\right)$. $\mathrm{BOD}_{5}$ is a measure of biological self-purification of water, while COD-Mn indicates the amount of dissolved oxygen necessary for oxidation of the total organic matter present in a water sample. Since the majority of substances can be fully chemically oxidized and only partially biologically degraded, COD-Mn generally has higher values than $\mathrm{BOD}_{5}$. High values of $\mathrm{BOD}_{5}$ are a consequence of organic pollution of the water (caused by industrial wastewaters, agriculture, etc.) and have a negative impact on the aquatic environment, such as reduction of oxygen concentration, resulting in a decline in water quality. Main sources of organic pollution are non-purified urban wastewaters, sewage and industrial wastewaters, and the most drastic consequence of such water pollution is fishkill [26].

\subsubsection{Five-Day Biochemical Oxygen Demand $\left(\mathrm{BOD}_{5}\right)$}

For very good quality of the Karašica River surface water, the Decree (Official Gazette 73/13) defines the limiting value of the 50th percentile of $\mathrm{BOD}_{5}$ at $1.2 \mathrm{mg} \mathrm{O} / \mathrm{L}$, and for good quality at 3.3 $\mathrm{mg} \mathrm{O}_{2} / \mathrm{L}$. For the Vučica River, the limiting value of the 50 th percentile of $\mathrm{BOD}_{5}$ for very good quality is set at $2 \mathrm{mg} \mathrm{O}_{2} / \mathrm{L}$, and for good quality at $5 \mathrm{mg} \mathrm{O}_{2} / \mathrm{L}$.

The lowest determined value of the 50th percentile in the Karašica River surface water was $1.5 \mathrm{mg}$ $\mathrm{O}_{2} / \mathrm{L}$, and was determined in the year 2009 at sampling site 21012 (Figure 3) (Appendix A, Table A3). The highest value was determined in 2002 at sampling station 21019 and amounted to $14.4 \mathrm{mg} \mathrm{O}_{2} / \mathrm{L}$. The lowest determined value of the 50th percentile of $\mathrm{BOD}_{5}$ in the Vučica River surface water was $1.72 \mathrm{mg} \mathrm{O}_{2} / \mathrm{L}$ and was determined in 1999 at sampling station 21020, while the highest value was measured in 2001 at sampling station 21007 and amounted to $6.36 \mathrm{mg} \mathrm{O}_{2} / \mathrm{L}$ (Figure 3) (Appendix A, Table A4). Considering the values of $\mathrm{BOD}_{5}$, the quality of the Karašica River surface water at sampling station 21012 in the years 1998 and 1999 cannot be described as good, in the period 2002-2014 it can be described as good, while during the year 2015 the value of the 50th percentile again exceeds the limiting value of good quality. Based on $\mathrm{BOD}_{5}$ values, the quality of surface water at sampling station 21019 can be categorised as good only in 2012 and 2013, after which the value of the 50th percentile again exceeds the limiting value of good condition. The condition of surface water at sampling station 21021 can be described as good in 1999, 2012 and 2013, after when the value of the 50th percentile exceeds the limiting value.

Based on the obtained $\mathrm{BOD}_{5}$ values, the quality of the Vučica River surface water at sampling station 21007 can be described as good, except in 1998, 2001 and 2002. Interestingly, based on the BOD value, the quality of the surface water at sampling station 21020 in 1998 and 1999 can be characterised as very good. However, according to the determined value of the 50th percentile in the years 2012, 2013 and 2015, it can be described as good, while BOD 5 in 2014 exceeds the limiting value of good quality. Generally, determined values of the 50th percentile of $\mathrm{BOD}_{5}$ for both rivers are lower than median annual value published by Munjko et al. [18].

In order to determine $\mathrm{BOD}_{5}$ change in the analysed period and to predict its change in the period between 2016 and 2020, linear regression analysis was applied on the data available for two sampling stations, 21012 and 21007. These two stations were chosen due to the longest data series; besides, sampling station 21007 is positioned after the confluence of the Karašica River to the Vučica River. Linear regression analysis applied on $\mathrm{BOD}_{5}$ values observed on the Karašica River (21012), with prediction period of five years and confidence interval of $95 \%$, shows no trend. The same analysis of the $\mathrm{BOD}_{5}$ for the Vučica River (21007), after the confluence of the Karašica River, shows the same result. These results lead to the conclusion that regarding $\mathrm{BOD}_{5}$, water quality status of both rivers can be expected to remain constant (Figure 3). 

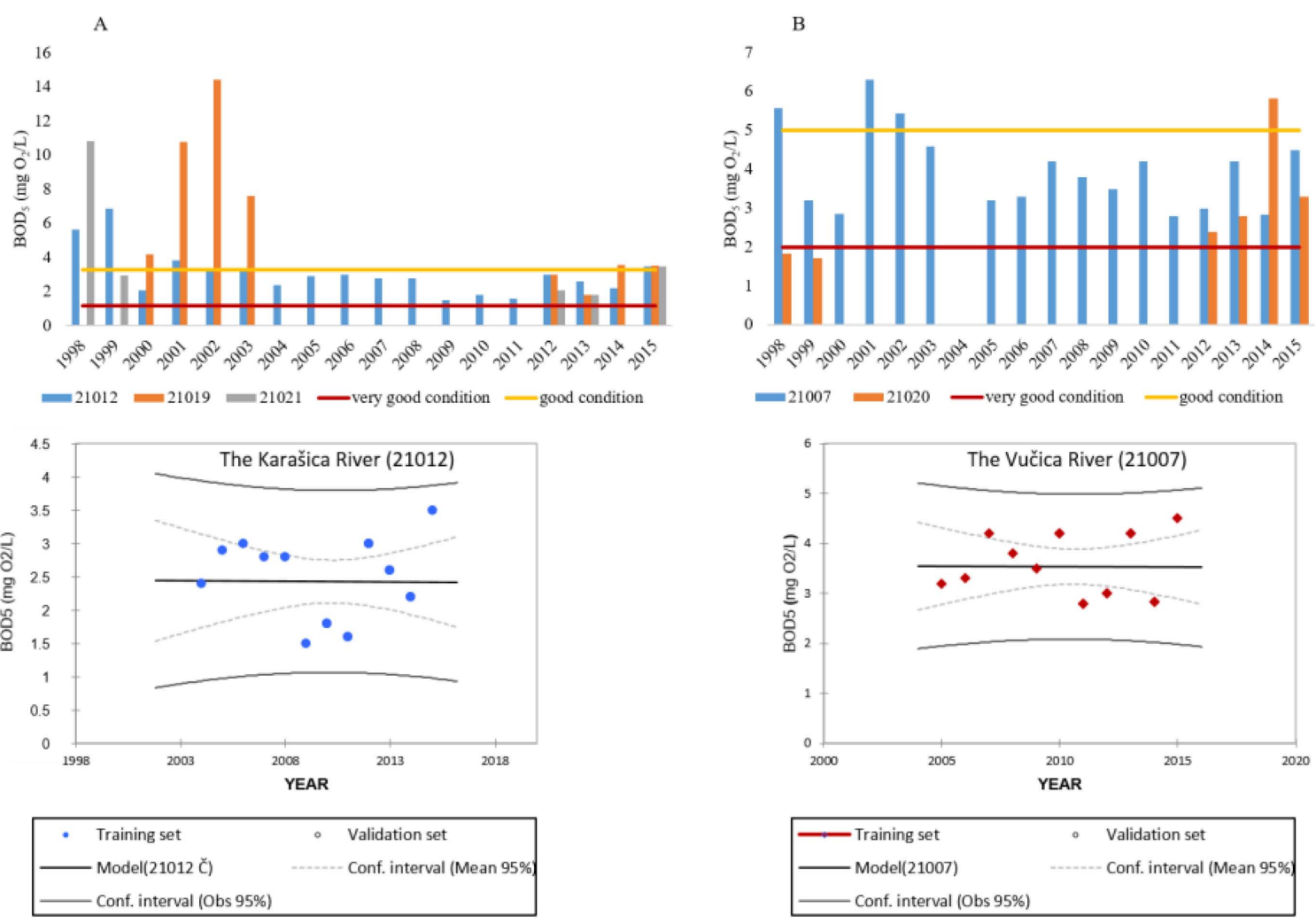

Figure 3. Water oxygenation, $\mathrm{BOD}_{5}$, of the $(\mathbf{A})$ Karašica and (B) Vučica Rivers surface water during the studied period (1998-2015) and a five-year prediction (2016-2020).

In the period between 1992 and 2006, median $\mathrm{BOD}_{5}$ values in European rivers decreased from 5 to $2 \mathrm{mg} \mathrm{O}_{2} / \mathrm{L}$, and in the Danube basin from 3 to $2.6 \mathrm{mg} \mathrm{O}_{2} / \mathrm{L}$ [31]. Gvozić et al. (2012) reported similar results for the Drava River: median $\mathrm{BOD}_{5}$ values ranged from 2.5 to $2.91 \mathrm{mg} \mathrm{O}_{2} / \mathrm{L}$, respectively, and showed a gradual increase along the river passage downstream. The observed trend was linked with the anthropogenic activity in the surrounding region. To be specific, the lower Drava River flow is a wastewater recipient for a number of cities, towns and villages situated along the river banks [27].

Abu and Egenonu (2008) reported low BOD $_{5}$ values in New Calabar River (2.24 $\left.\mathrm{mg} \mathrm{O}_{2} / \mathrm{L}\right)$ and Kubanni River (1.83 $\mathrm{mg} \mathrm{O}_{2} / \mathrm{L}$ ) in Kaduna, Northwest Nigeria [28]. However, Wakawa et al. (2008) reported high $\mathrm{BOD}_{5}$ values for Challawa River in Kano State, Northern Nigeria, with mean concentrations ranging between 10 to $30 \mathrm{mg} \mathrm{O}_{2} / \mathrm{L}$, respectively. Pollution of the rivers was directly linked with the industrial effluent discharges [32].

\subsubsection{Chemical Oxygen Demand (COD-Mn)}

For very good quality of the Karašica River surface water, the limiting value of the 50th percentile of COD-Mn is set at $1.8 \mathrm{mg} \mathrm{O}_{2} / \mathrm{L}$, and for good quality at $5.5 \mathrm{mg} \mathrm{O}_{2} / \mathrm{L}$ (The Decree (Official Gazette 73/13)). For the Vučica River, the limiting value of the 50th percentile of very good quality is set at $2.5 \mathrm{mg} \mathrm{O}_{2} / \mathrm{L}$, and for good quality at $5.5 \mathrm{mg} \mathrm{O}_{2} / \mathrm{L}$.

The value of the 50th percentile of COD-Mn in the Karašica River surface water was within the range from $3.5 \mathrm{mg} \mathrm{O}_{2} / \mathrm{L}$ (in 2013, at sampling station 21019) to $10.1 \mathrm{mg} \mathrm{O}_{2} / \mathrm{L}$ (in 2014, at the same sampling station) (Figure 4) (Appendix A, Table A3). For Vučica River surface water, value of the 50th percentile of COD-Mn was within the range from $2.775 \mathrm{mg} \mathrm{O}_{2} / \mathrm{L}$ (in 1998, at sampling station 21020) to $10.9 \mathrm{mg} \mathrm{O}_{2} / \mathrm{L}$ (in 2014, at the same sampling station) (Appendix A, Table A4). 

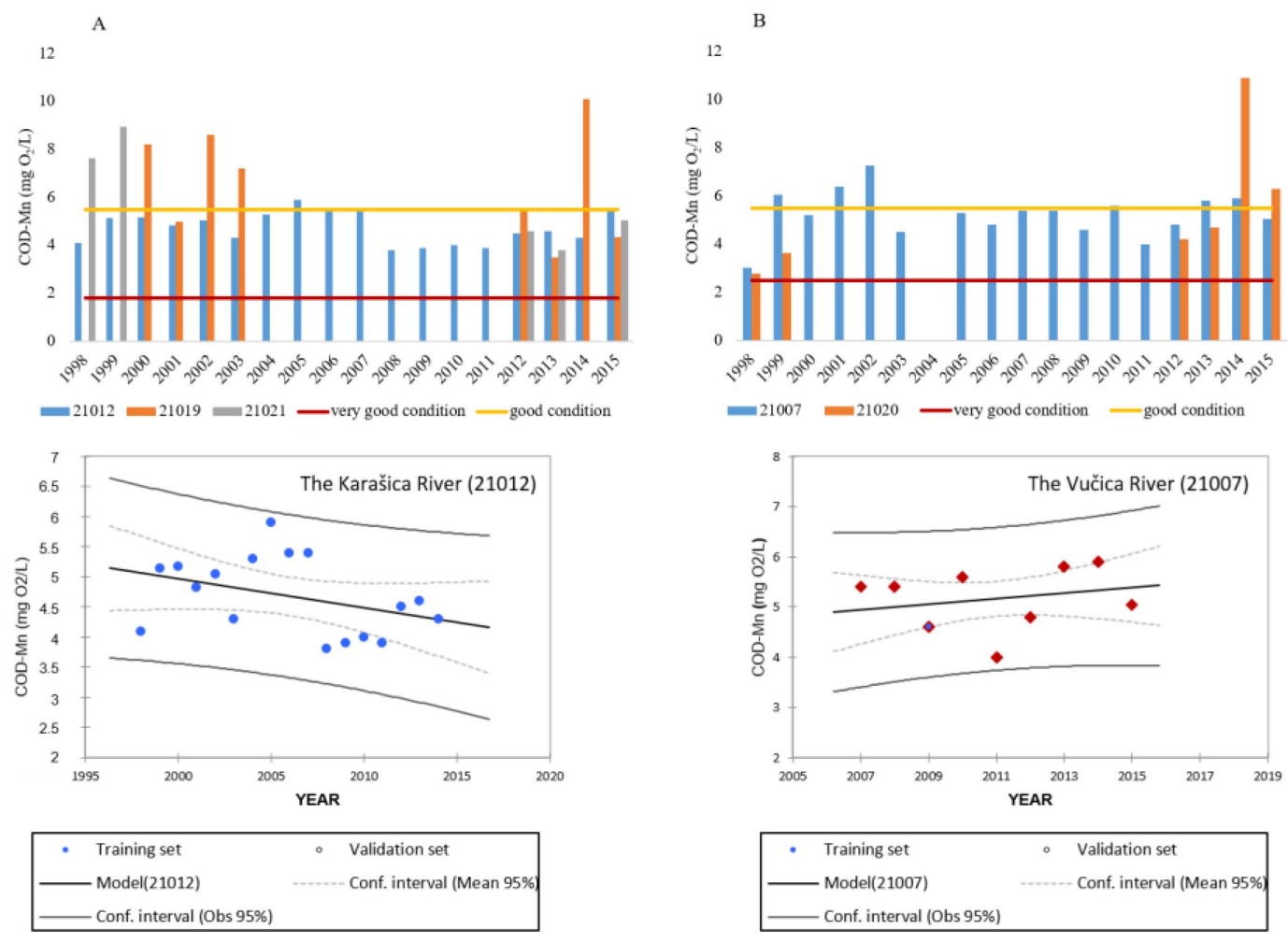

Figure 4. Water oxygenation, COD-Mn, of the (A) Karašica and (B) Vučica Rivers surface water during the studied period (1998-2015) and a five-year prediction (2016-2020).

Based on the COD-Mn values determined at sampling station 21012, the quality of the Karašica River surface water can be described as good, except in the year 2005. Considering the same parameter, the quality of the Karašica River surface water at sampling station 21019 was good in 2001, 2012, 2013 and 2015, and at the sampling site 21021 in 2012, 2013 and 2015. During the remaining years, the determined values of COD-Mn in the Karašica River surface water exceed the limiting value of the 50th percentile, meaning that the water quality can no longer be described as good.

Based on COD-Mn values, quality of the Vučica River surface water at sampling station 21007 can be described as good for years 1998, 2000, 2003-2009, 2011, 2012 and 2015. At sampling site 21020, in 2014 and 2015, COD-Mn values exceeded the limit value of the 50th percentile, but during the rest of the years, water quality can be characterised as good.

The data presented in this paper are generally lower than the data published previously [18]. During the analysed period, a slight increase in the values of COD-Mn and $\mathrm{BOD}_{5}$ in the Karašica and Vučica River surface water was observed (for some years and some sampling sites), and is presumed to be a consequence of increased concentration of suspended organic matter, which itself is a consequence of increased soil erosion, increased amount of precipitations and/or increased water flow. Linear regression analysis applied on the COD-Mn values observed on the Karašica River (21012) with prediction period of five years shows slight decreasing trend. The same analysis of the COD-Mn for the Vučica River (21007), after the confluence of the Karašica River, shows increasing trend. These results lead to the conclusion that chemical pollution basically originates from the Vučica River sub-catchment (Figure 4).

Median COD value for the Drava River surface water reported by Gvozdić et al. (2012) ranged from 3.3 to $3.8 \mathrm{mg} \mathrm{O}_{2} / \mathrm{L}$, respectively, and showed a gradual increase along the river passage downstream. The obtained COD values can be assigned to nutrients and organic components of the water, and indicate that organic compounds that fall into the Drava River are not completely destroyed by the self-purification processes. Since the surrounding area is populated, the observed 
trend was linked with domestic sewage input and with agricultural activities. In addition, surface run-off resulting from soil erosion, lumbering industry and dredging activities may also lead to the contamination of the river [27].

Robson et al. (2006) analysed stream quality in a small urbanised catchment, the Charlton Brook in the United Kingdom. The value of $\mathrm{BOD}_{5}$ was in the range from 1.315 to $2.915 \mathrm{mg} / \mathrm{L}$, while the COD value was between $18.877-31.429 \mathrm{mg} / \mathrm{L}$, respectively. The study showed an increase of $\mathrm{BOD}_{5}$ from the upstream rural to the downstream urban areas, confirming that there was a deterioration in water quality caused by anthropogenic activities [33].

Abu and Egenonu (2008) reported low COD value for New Calabar River in Nigeria [28]. High COD values have been observed for Challawa River in Kano State with mean concentrations ranging between 170 to $260 \mathrm{mg} \mathrm{O}_{2} / \mathrm{L}$, respectively [32]. Osibanjo et al. (2011) also reported high COD values for the water samples from rivers Ona and Alaro, Nigeria. The authors attributed these to leaching from dumpsites, agricultural and urban runoffs [34].

Eisakhani and Malakahmad (2009) in the study conducted within the Bertam River and its tributaries in Cameron Highlands, Malaysia, reported high COD values: $49.53 \mathrm{mg} / \mathrm{L}$ (the Bertam River) and $40 \mathrm{mg} / \mathrm{L}$ (the Burong River), respectively during high water flow. While much lower concentrations were determined during average water flow, the Jasar River has shown high COD level of $33 \mathrm{mg} / \mathrm{L}$, respectively during average water flow, probably due to the domestic wastewater discharge from the Tanah Rata town. The COD showed the same trend as total nitrogen and total phosphorus, linking obtained results with the anthropogenic activities [29].

\subsection{Nutrient Concentration}

The analysis of the nutrient concentration in the surface water of the studied rivers includes the concentration of nitrates $(\mathrm{mg} \mathrm{N} / \mathrm{L})$, total nitrogen $(\mathrm{mg} \mathrm{N} / \mathrm{L})$, orthophosphates $(\mathrm{mg} \mathrm{P} / \mathrm{L})$ and total phosphorus (mg P/L), since these parameters are determined by the Decree (Official Gazette 73/13) as main physical-chemical parameters of water quality.

Nitrates are important nutrients necessary for the growth and development of algae and other aquatic plants, however, high concentrations of nitrates $(>90 \mathrm{mg} / \mathrm{L})$ have a toxic effect on aquatic organisms [26]. Rain, snow, fog and decomposition of organic matter are all pathways that naturally increase the content of nitrates. Application of fertilisers in agriculture is a major cause of increase of the nitrogen concentration in soil and water (by erosion of soil), whereas the other cause is wastewater. Increased concentrations of nutrients (not only nitrogen but phosphorus as well) lead to increased development of algae and aquatic plants, which eventually leads to increasing overload of aquatic ecosystems and development of eutrophication [26]. Thus, the Annex 10 of the Decree (Official Gazette 73/13) defines the limit values of the 50th percentile of concentration of nitrates and total phosphorus as indicators of eutrophication of aquatic ecosystems. According to Annex 10, a river has a very good water quality if its 50th percentile for nitrogen content is in the range from 0.4 to $1 \mathrm{mg} / \mathrm{L}$, and for total phosphorus in the range from 0.02 to $0.15 \mathrm{mg} / \mathrm{L}$. A river has a good water quality if its 50th percentile for the nitrogen content is in the range from 0.7 to $2.5 \mathrm{mg} / \mathrm{L}$ and for total phosphorus in the range $0.06-0.35 \mathrm{mg} / \mathrm{L}$.

Annex 2C, Table 6 of the Decree (Official Gazette 73/13) sets the limiting value of the 50th percentile for very good quality of the Karašica River surface water at $0.7 \mathrm{mg} \mathrm{N} / \mathrm{L}$ for nitrates, for total nitrogen at $1.1 \mathrm{mg} \mathrm{N} / \mathrm{L}$, for orthophosphates at $0.03 \mathrm{mg} \mathrm{P} / \mathrm{L}$, and for total phosphorus at $0.05 \mathrm{mg} \mathrm{P} / \mathrm{L}$. For good water quality of the Karašica River, the limiting value is set at $1.3 \mathrm{mg} N / \mathrm{L}$ for nitrates, at $2 \mathrm{mg} \mathrm{N} / \mathrm{L}$ for total nitrogen, at $0.1 \mathrm{mg} \mathrm{P} / \mathrm{L}$ for orthophosphates, and at $0.2 \mathrm{mg} \mathrm{P} / \mathrm{L}$ for total phosphorus. For very good water quality of the Vučica River surface water, the limiting value of the 50th percentile is set at $1 \mathrm{mg} \mathrm{N} / \mathrm{L}$ for nitrates, at $1.4 \mathrm{mg} \mathrm{N} / \mathrm{L}$ for total nitrogen, at $0.09 \mathrm{mg} \mathrm{P} / \mathrm{L}$ for orthophosphates, and at $0.13 \mathrm{mg} \mathrm{P} / \mathrm{L}$ for total phosphorus. The limiting value for good water quality of the Vučica River is set at $2 \mathrm{mg} \mathrm{N} / \mathrm{L}$ for nitrates, at $2.6 \mathrm{mg} \mathrm{N} / \mathrm{L}$ for total nitrogen, at $0.2 \mathrm{mg} \mathrm{P} / \mathrm{L}$ for orthophosphates, and at $0.3 \mathrm{mg} \mathrm{P} / \mathrm{L}$ for total phosphorus. 


\subsubsection{Nitrogen Compounds}

The lowest value of the 50th percentile of nitrate concentration in the Karašica River surface water was determined in the year 2012 at sampling sites 21019 and 21021, and it amounted to $0.124 \mathrm{mg}$ N/L (Appendix A, Table A5). The lowest value of the 50th percentile of nitrate concentration in the Vučica River surface water was determined in the same year, at sampling site 21020, and it amounted to $0.1862 \mathrm{mg} \mathrm{N} / \mathrm{L}$ (Appendix A, Table A6). The highest value of nitrate concentration in the Karašica River was determined in 2004 at sampling site 21012-3.164 mg N/L, and in the Vučica River in 2005 at sampling site 21007-1.808 mg N/L. As can be seen on Figure 5, during the analysed period, the value of the 50th percentile of nitrate concentration in the Karašica River surface water varies greatly, and a similar situation was observed in the case of the 50th percentile of the nitrate concentration in the Vučica River surface water.

Considering the concentration of nitrates, the quality of the Karašica River surface water at sampling site 21012 can be characterized as good to very good (depending on the year), with significant deterioration of quality in 2004 and 2005. Based on the available data, water quality at sampling sites 21021 and 21019 can be described as very good, except in 2001 and 2002, when at sampling site 21019 the water quality can be characterised as good. Considering the value of the 50th percentile of nitrates in the Vučica River surface water, water quality at sampling site 21020 can be characterized as very good. The same situation was observed for sampling site 21007, except in 2005, 2008, 2010 and 2013, when the water quality can be described as good. It is important to point out that the observed and analysed values were lower than the ones published by Vidaček et al. in 1999 [19].

Linear regression analysis applied on the nitrate concentration values observed on the Karašica River (21012) with prediction period of five years and 95\% confidence interval shows slight increasing trend. The same analysis of the nitrates for the Vučica River (21007), after the confluence of the Karašica River, shows an even less increasing trend, due to its higher discharge and smaller portion of agricultural land (Figure 5).
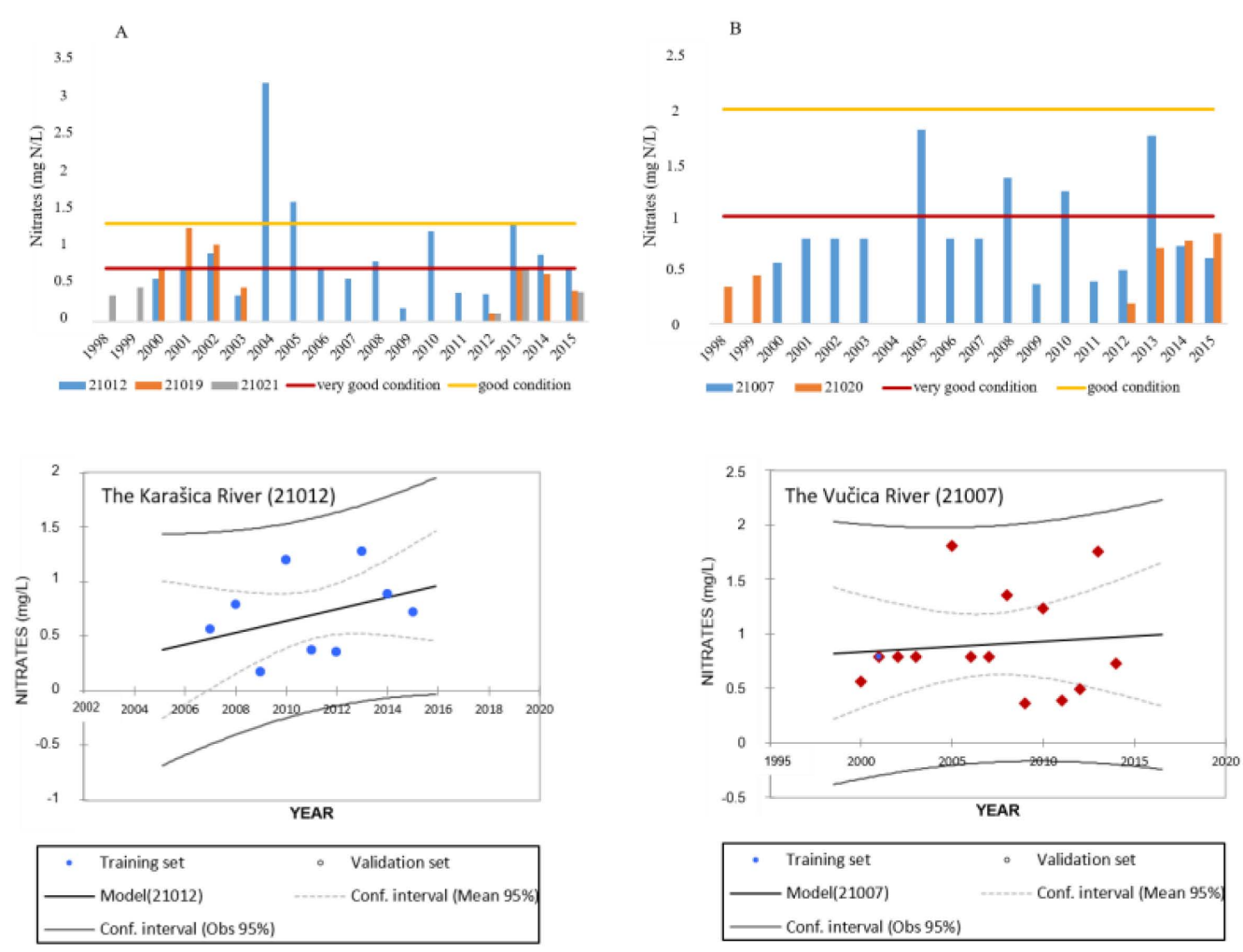

Figure 5. Content of nitrates in the (A) Karašica and (B) Vučica Rivers surface water during the studied period (1998-2015) and a five-year prediction (2016-2020). 
Regarding limiting values of the 50th percentile defined in Annex 10 of the Decree (Official Gazette 73/13), which considers the nitrates content as an indicator of degree of eutrophication, the quality of the surface water of the Karašica River at sampling sites 21021 and 21019 can be described as very good (except in 2001 and 2002, at the site 21,19), and at sampling site 21012 as good to very good (except in 2004). A similar situation was observed in the case of the Vučica River surface water, regarding level of eutrophication at sampling site 21020 when the water quality was determined to be very good quality (except in 2012, when quality of water was defined as good), and at the site 21007 where the water was in good of very good quality (depending on the year).

Increased values of total nitrogen indicate pollution of the water body by inadequately purified wastewaters (industry, sewage) and by excessive use of mineral (primarily nitrogen) fertilizers in agricultural production [35]. The value of the 50th percentile of total nitrogen content in the Karašica River surface water was in the range from 0.5078 (in 2012, at sampling site 21019) to $3.581 \mathrm{mg} \mathrm{N} / \mathrm{L}$ (in 2004, at the site 21012) (Appendix A, Table A5), while the range in the Vučica River surface water was from 0.729 (in 2009, at sampling site 21007) to $2.275 \mathrm{mg}$ N/L (in 2013, at the site 21007) (Appendix A, Table A6). Linear regression analysis applied on total nitrogen values observed on both rivers $(21012,21007)$ with prediction period of five years and $95 \%$ confidence interval shows slight increasing trend (Figure 6).
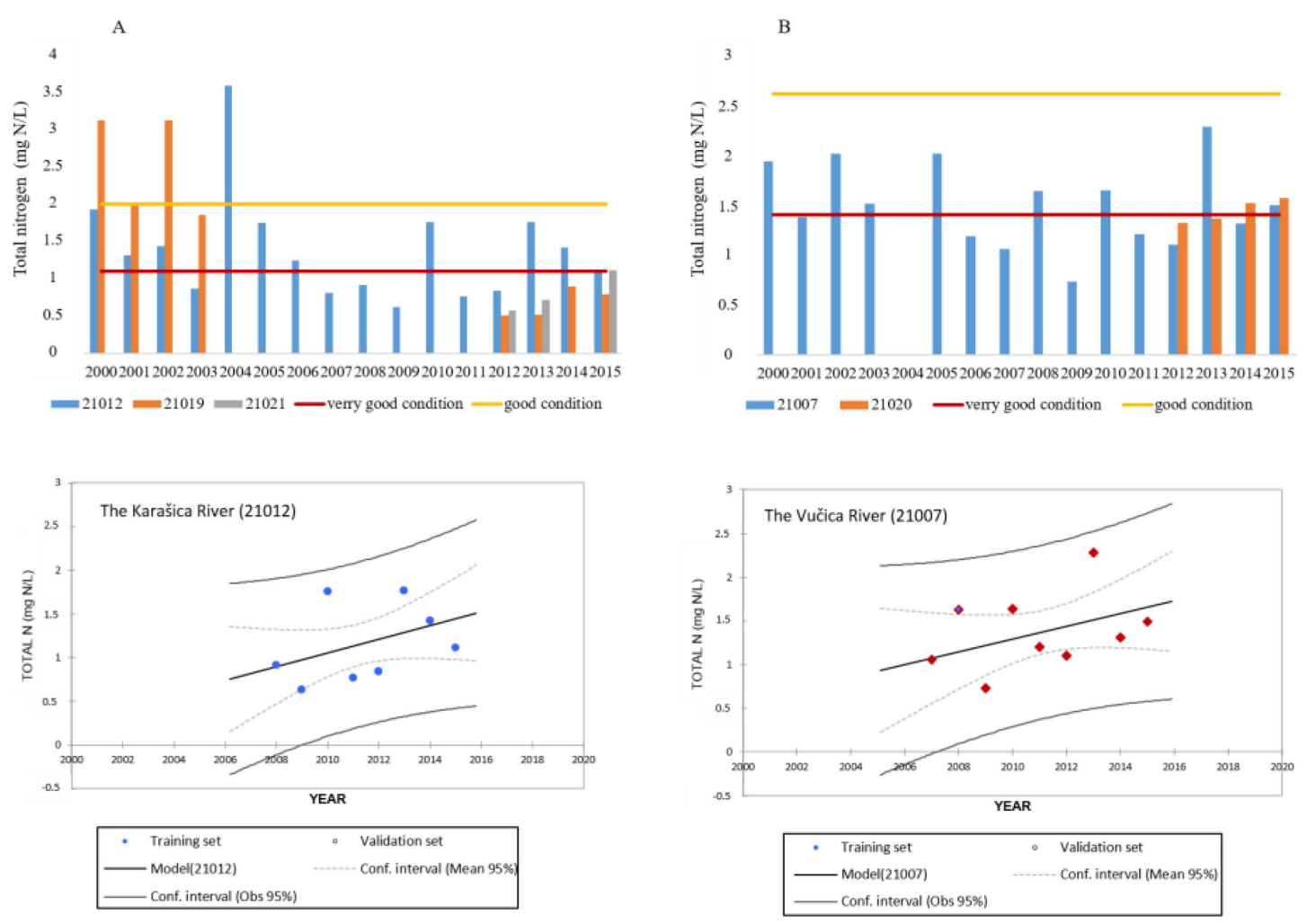

Figure 6. Content of total nitrogen in the (A) Karašica and (B) Vučica Rivers surface water during the studied period (1998-2015) and a five-year prediction (2016-2020).

Considering the 50th percentile of total nitrogen content, the quality of the Karašica River surface water at sampling site 21012 can be described as good, except in 2003, 2007-2009, 2011 and 2012 when it is very good, and in 2004 when the water quality deteriorates and cannot be described as good. Water quality at sampling site 21019 in the period 2000-2002 cannot be described as good, in 2003 is good, and during the period 2012-2015 very good. In the years 2012 and 2013, the water quality at sampling site 21021 is very good, but in the year 2015 it is good. The quality of the Vučica River surface water at sampling site 21020 in 2012 and 2013 is very good, but in 2014 and 2015 it is good. Quality of 
the surface water at location 21007 varies greatly, in 2000-2005, 2008, 2010, 2013 and 2015 water quality is good, and in the remaining years very good.

Gvozdić et al. (2012) reported that the median concentration of nitrates in the River Drava surface water is relatively low compared to other rivers in western Europe (4.4-3.8 mg N/L) [27]. These values are similar to those obtained in the rivers in eastern Europe, for instance in the Danube and the Sava River (2.1-2.0, 1.6-0.95 and 1.3-1.2 mg N/L, respectively) [36,37].

Similar research of Slovenian rivers (Globevnik et al. (2006)) showed that hydro-morphological and chemical pressures from water treatment plants and agglomerations, industrial plants and diffused pollution from agriculture (nitrogen) are the main reasons for the non-attainment of environmental objectives. Though consumption of mineral fertilisers and plant nutrients in Slovenia has reached more or less steady state in recent years, the quantities are still too high to reduce the risk to the water environment [38].

Neal et al. (2006) conducted a monitoring study on the upper River Thames and its tributaries (the United Kingdom). Only for two tributaries of the River Thames (the Pang and the Kennet), which were monitored for over five years, nitrate concentrations have increased over time. For the main stream of the River Thames, which was also monitored for over five years, there is no clear increase over time [39].

Eisakhani and Malakahmad (2009) in the study conducted within the Bertam River and its tributaries in Malaysia, reported total nitrogen concentration of $17 \mathrm{mg} / \mathrm{L}$ at the Bertam River and $9.6 \mathrm{mg} / \mathrm{L}$ at the Burong River, respectively during high water flow. The authors linked high level of nitrates at the Burong River to the extend use of pesticides and fertilizers at surrounding farming area. As the Bertam River passes through Tanah Rata town, domestic wastewater was determined to be the main cause of high nitrates [29].

A research conducted by Dutch researchers Van Grinsvena et al. (2016) on the nitrate concentrations in fresh surface waters proved relatively low nitrate concentrations compared to the other European rivers, and decreasing trend mostly due to implementation of the Water Framework Directive measures [40].

\subsubsection{Phosphorus Compounds}

The amount of the 50th percentile of concentration of orthophosphates in the Karašica River surface water was in the range from $0.0282 \mathrm{mg} \mathrm{P} / \mathrm{L}$ (in 2013, at sampling site 21019) to $0.3655 \mathrm{mg}$ $\mathrm{P} / \mathrm{L}$ (in 2000, at sampling site 21019) (Appendix A, Table A7), and in the Vučica River surface water in the range from 0.0348 (in 2013, at sampling site 21020) to $0.184 \mathrm{mg} \mathrm{P/L}$ (in 2002, at sampling site 21007) (Figure 7) (Appendix A, Table A8). Considering this value, the quality of the Karašica River surface water at sampling site 21012 greatly varies and generally can be described as good, except in the years 2001, 2002, 2004, 2006, 2007, 2010 and 2014 when the condition deteriorates and cannot be described as good. Water quality at sampling sites 21019 and 21021 can be described as good (in the period 2012-2015). Based on the amount of the 50th percentile of the orthophosphates content, the quality of the Vučica River surface water can be described as very good, except in 2001, 2002 and 2010 at sampling site 21007, when it can be characterized as good.

The amount of total phosphorus indicates the degree of water pollution, i.e., the presence of faecal wastewater, chemical fertilisers and detergents (surfactants) [41]. The determined value of the 50th percentile of the total phosphorus content in the Karašica River surface water was in the range from 0.08 (in 2015, at sampling site 21019) to $0.9385 \mathrm{mg} \mathrm{P} / \mathrm{L}$ (in 2000, at the site 21019), and in the Vučica River surface water in the range from 0.07 (in 2012, at sampling site 21020) to $0.459 \mathrm{mg} \mathrm{P} / \mathrm{L}$ (in 2002, at the site 21007) (Appendix A, Tables A7 and A8).

The quality of the Karašica River surface water at sampling site 21012 can be described as good, except during the period from 2000 to 2003 and in 2006, when water quality deteriorates and cannot be described as good. Water quality at sampling stations 21019 and 21021 in the period from 2012 to 2015 can be characterised as good. Linear regression analysis applied on orthophosphate values observed 
on the Karašica River (21012) with prediction period of five years and 95\% confidence interval shows slight decreasing trend. The same analysis of the COD-Mn for the Vučica River (21007), after the confluence of the Karašica River, shows the same trend. These results lead to the conclusion that concentration of orthophosphates in both sub-catchments is decreasing due to reduction of mineral fertilizers application according to the Nitrate Directive [42] (Figure 7).
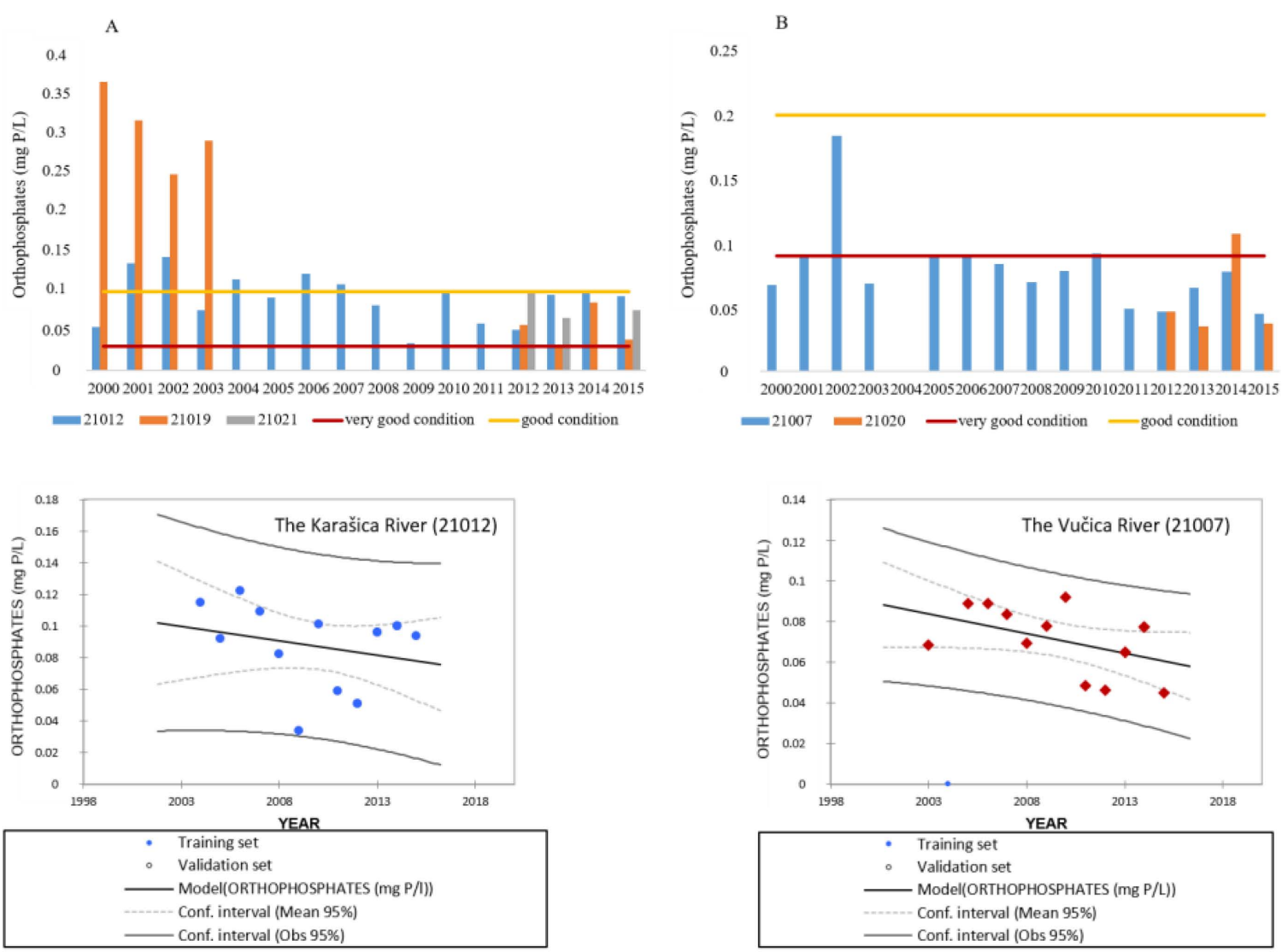

Figure 7. Content of orthophosphates in the (A) Karašica and (B) Vučica Rivers surface water during the studied period (1998-2015) and a five-year prediction (2016-2020).

Considering the observed content of total phosphorus, the quality of the Vučica River surface water at sampling site 21020 can be described as good, and in 2015 as very good. Water quality at sampling site 21020 in 2012 and 2013 is very good, but in 2014 and 2015 it can be characterized as good.

When the 50th percentile of total phosphorus content is used as an indicator of the degree of eutrophication (Annex 10 of the Decree (Official Gazette 73/13)), the quality of this water body can be described as good, with some exceptions-sampling site 21019 (in 2000) and site 21007 (in 2002), when water quality is less than good. Linear regression analysis applied on total phosphorus values observed on the Karašica River (21012) with prediction period of five years and 95\% confidence interval shows only slightly increasing trend. The same analysis of the COD-Mn for the Vučica River (21007), after the confluence of the Karašica River, shows no trend (Figure 8).

Eisakhani and Malakahmad (2009) in the study conducted within the Bertam River and its tributaries in Malaysia, reported total phosphorus concentration of $14 \mathrm{mg} \mathrm{P} / \mathrm{L}$ at the Bertam River and $8.6 \mathrm{mg} \mathrm{P} / \mathrm{L}$ at the Burong River, respectively during high water flow. The obtained results indicate that agricultural runoff contains fertilizers and is probably the major cause for high concentration of phosphorous [29]. 

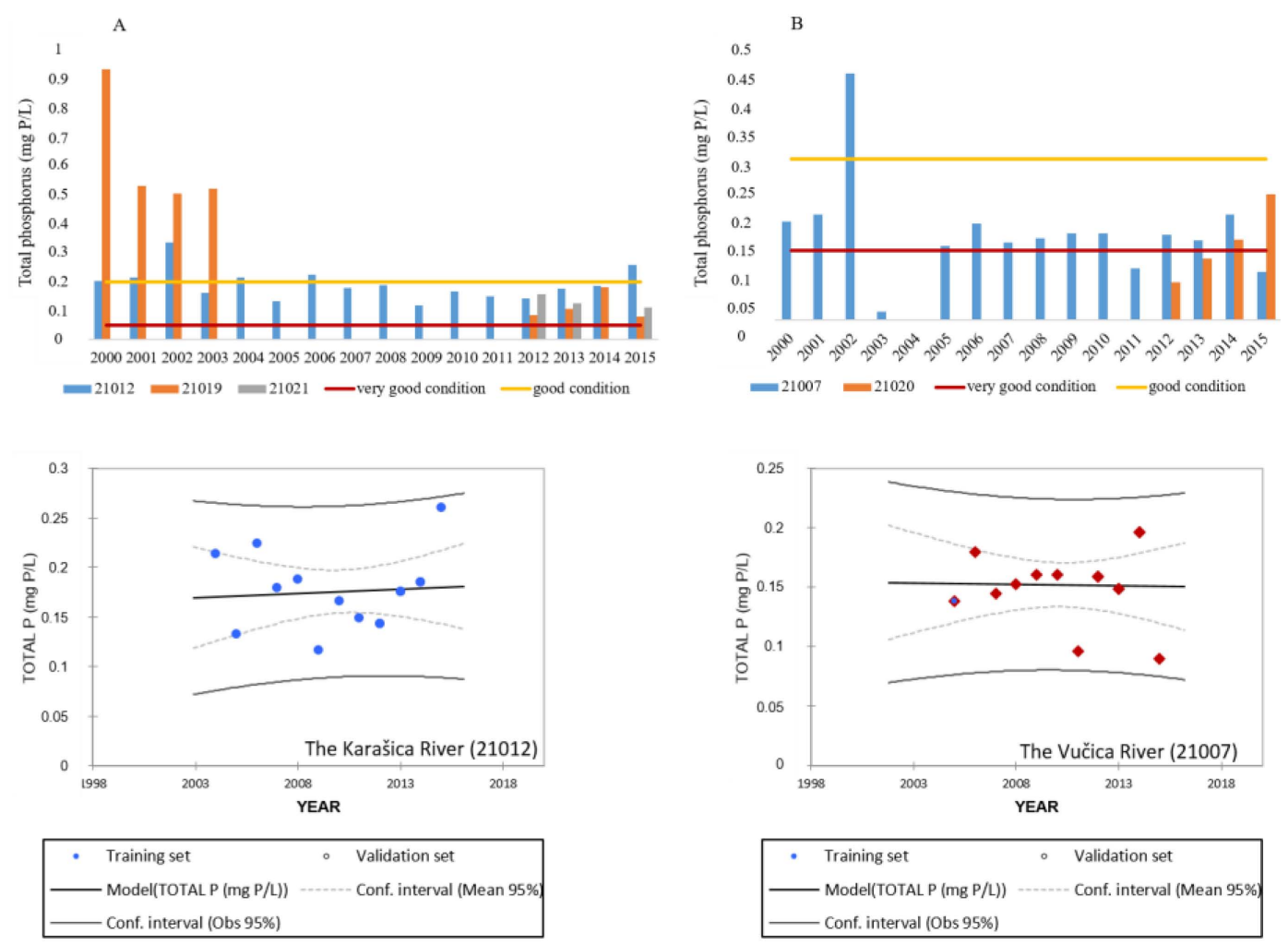

Figure 8. Content of total phosphorus in the (A) Karašica and (B) Vučica Rivers surface water during the studied period (1998-2015) and a five-year prediction (2016-2020).

Judova and Jansky (2005) in a three-year study conducted in rural areas of the Czech Republic (Slapanka River catchment) reported mean phosphates concentration ranging from 0.08 to $0.41 \mathrm{mg} / \mathrm{L}$, respectively. The study also reported mean nitrates concentration $(5.31-10.55 \mathrm{mg} / \mathrm{L})$, mean $\mathrm{BOD}_{5}$ (3.82-12.37 mg/L), and mean COD (8.23-12.37 mg/L), respectively. The authors linked the lowest values of analysed parameters to the extreme self-purification capacity of the stream. The runoff from cultivated farmlands and wastewater from residences without adequate sanitation were identified as the main pollution sources. Contamination originating from agriculture is also a problem in this area [43].

Ntislidou et al. (2012) in a case study from river basin Kosynthos, in Greece conducted in June 2011, reported levels of phosphates ranging from 0.022 to $0.146 \mathrm{mg} / \mathrm{L}$, respectively. The same study reported nitrate levels to be in the range of 0.139 to $1.539 \mathrm{mg} / \mathrm{L}$, and $\mathrm{BOD}_{5}$ ranging from 0.64 to $2.32 \mathrm{mg} / \mathrm{L}$, respectively. The authors linked obtained results with livestock breeding $\left(\mathrm{BOD}_{5}\right.$, nitrates and phosphates), agriculture (nitrates and phosphates) and urban waste waters (nitrates and phosphates) [44].

Iqbal et al. (2013) found phosphates values ranging from $62.37 \mu \mathrm{g} / \mathrm{L}$ to $155 \mu \mathrm{g} / \mathrm{L}$, within the Dudhganga catchment area in India. The nitrates content in the study area was also low and ranged from $0.15 \mathrm{mg} / \mathrm{L}$ to $0.99 \mathrm{mg} / \mathrm{L}$, respectively. The authors linked obtained results to the mostly forest land cover and to reduced anthropogenic activity in the surrounding region [45].

$\mathrm{Xu}$ and Zhang (2016) in the study conducted within the upper catchment of Miyun Reservoir in China reported total phosphorus values ranging from 0.02 to $0.46 \mathrm{mg} / \mathrm{L}$, respectively. The authors found that the total phosphorus concentrations were positively correlated with the proportion of arable land, grassland, and residential land, and negatively correlated with the forest proportion [46].

Study of Crossman et al. (2014) of the River Thames, evaluates complexity of the water quality problem on an example of a major river system in the United Kingdom (the River Thames) and its response to alterations in climate, land use and water resource allocations. This study showed that 
the soluble reactive phosphorus from diffuse and point sources varies seasonally in the River Thames. The authors proved that diffuse sources of phosphorus from agriculture dominate during periods of high runoff, and point sources during low flow periods [47].

The loss of phosphorus examined within the large river delta areas in Northern Belgium, The Netherlands and North-West Germany, proved different vulnerability to phosphorus loss depending on the soil texture (sandy, peaty and clayey soils) [48].

\subsection{Concentration of Heavy Metals}

Heavy metals are classified as specific pollutants, and their effect on the environment is characterised by high toxicity, bioaccumulation, biomagnification and participation in biogeochemical cycles. These chemical elements occur naturally in the environment in very small amounts, thus various anthropogenic sources (combustion of fossil fuels, chemical industry, oil industry, plastics industry, herbicides, pesticides, mineral fertilisers, etc.) lead to a significant increase in their concentration [35]. Limit values for the content of a particular pollutant acceptable for specific ecological condition are given in Table 14, Annex 2C of the Decree (Official Gazette 73/13), and are expressed as average annual concentration (AAC) and maximum annual concentration (MAC). The limit value of copper, zinc and their compounds content for a specific ecological condition depends on the water hardness (mg $\mathrm{CaCO}_{3} / \mathrm{L}$ ). Croatian rivers are classified based on the water hardness in five categories. Surface waters of the Karašica-Vučica catchment area belong to the 5th category ( $\geq 200 \mathrm{mg} \mathrm{CaCO} / \mathrm{L}$ ). Table 14 defines limit values for arsenic (but only for selected surface water bodies of the Danube River water region), copper (AAC $>8.8 \mu \mathrm{g} / \mathrm{L}, \mathrm{MAC}$ is not applied), zinc (AAC-52 $\mu \mathrm{g} / \mathrm{L}, \mathrm{MAC}$ is not applied) and chromium (AAC-9 $\mu \mathrm{g} / \mathrm{L}, \mathrm{MAC}$ is not applied). The Decree on Changes and Additions to the Decree on Water Quality Standards (Official Gazette 78/15) defines the following average annual concentration (AAC) and maximum annual concentration (MAC) for remaining heavy metals: cadmium (AAC—0.25 $\mu \mathrm{g} / \mathrm{L}, \mathrm{MAC}-1.5 \mu \mathrm{g} / \mathrm{L}$ ), nickel (AAC—4 $\mu \mathrm{g} / \mathrm{L}, \mathrm{MAC}-34 \mu \mathrm{g} / \mathrm{L}$ ), lead $(\mathrm{AAC}-1.2 \mu \mathrm{g} / \mathrm{L}, \mathrm{MAC}-14 \mu \mathrm{g} / \mathrm{L}$ ) and mercury (AAC—not defined, MAC $-0.07 \mu \mathrm{g} / \mathrm{L}$ ). Limit values for cadmium and its compounds depend on water hardness. Limit values for manganese, iron and their compounds are not defined.

The data for the concentration of heavy metals in the Karašica River surface water was collected from two sampling sites $(21012,21021)$, and the number of data varied depending on the sampling site and year (Figure 9) (Appendix A, Table A9). For the Vučica River surface water data was available from two sampling sites $(21020,21007)$, and the number of available data also varied depending on the site and year (Figure 10). The analysis of available data shows that the content of heavy metals in the surface water of the sampling sites is within the legally defined limits (AAC and MAC). Only the values of mercury exceeded the MAC and were determined in 1998 and 1999 to be $0.128 \mu \mathrm{g} / \mathrm{L}$ at sampling site 21021 in 1999, $0.185 \mu \mathrm{g} / \mathrm{L}$ at the site 21020 in 1998, and $0.125 \mu \mathrm{g} / \mathrm{L}$ in 1999 at the same site. The available data indicates a slightly ascending trend of the concentration of heavy metals in the Karašica River surface water in the last several years. The exception is the concentration of manganese in the Karašica River and of lead in the Vučica River (both of which show a descending trend).

According to The Water Management Plan 2016-2021 [21], surface water quality of the Karašica River at sampling site 21021 can be described as moderate, and at two sites, 21012 and 21019, as good (Appendix A, Table A10). The quality of the Vučica River surface water at sampling site 21020 can be described as good, and at the site 21007 as moderate to good (considering $\mathrm{BOD}_{5}$, nitrates and total phosphorus). The decrease in value of some parameters compared to previously published data is a result of a temporary pause in industrial and agricultural production, and significant emigration during the war years. However, a slight increase of some parameters was detected in the last several years, which is probably a result of restored agricultural production. Since assessment reliability is marked as moderate, more reliable assessment requires continuous monitoring with frequent sampling, and analysis of additional parameters of the water quality, such as biological and hydro-morphological parameters. 
Gvozdić et al. (2015) conducted a study to determine concentration of selected metals in water samples from wells in eastern Croatia. The results of this study show elevated concentration of As, $\mathrm{Mn}$ and $\mathrm{Fe}$, while concentration of the remaining elements are below the maximum allowed concentration [49]. Various studies conducted in Croatia have proved that these elements (As, Mn, Fe) mainly originate from natural sources, as a result of geological composition of the soil [50,51].

Juračić et al. $(1986,1987)$ analysed heavy metals content in the Adige estuary in Italy. They have found $\mathrm{Ni}, \mathrm{Cd}, \mathrm{Zn}$ and $\mathrm{As}$ in the surface water of the upper part of the catchment, while $\mathrm{Cr}, \mathrm{Pb}$ and $\mathrm{Hg}$ have not been detected [52,53]. Benfenati et al. (1992) identified the presence of $\mathrm{Mn}$ and $\mathrm{Cu}$, in concentrations that are below the Italian legal limits [54]. Recently, Fuganti et al. (2005) detected considerable concentration of $\mathrm{Cr}(0.4 \mu \mathrm{g} / \mathrm{L})$ and As (up to $56 \mu \mathrm{g} / \mathrm{L}$ ) [55]. Presence of heavy metals in Adage estuary surface water was linked to an important leather production district, tanneries and paper industries in the southern part of the catchment [56]. High values of As were linked to natural sources, since they were found in water that leaches volcanic rocks [55].
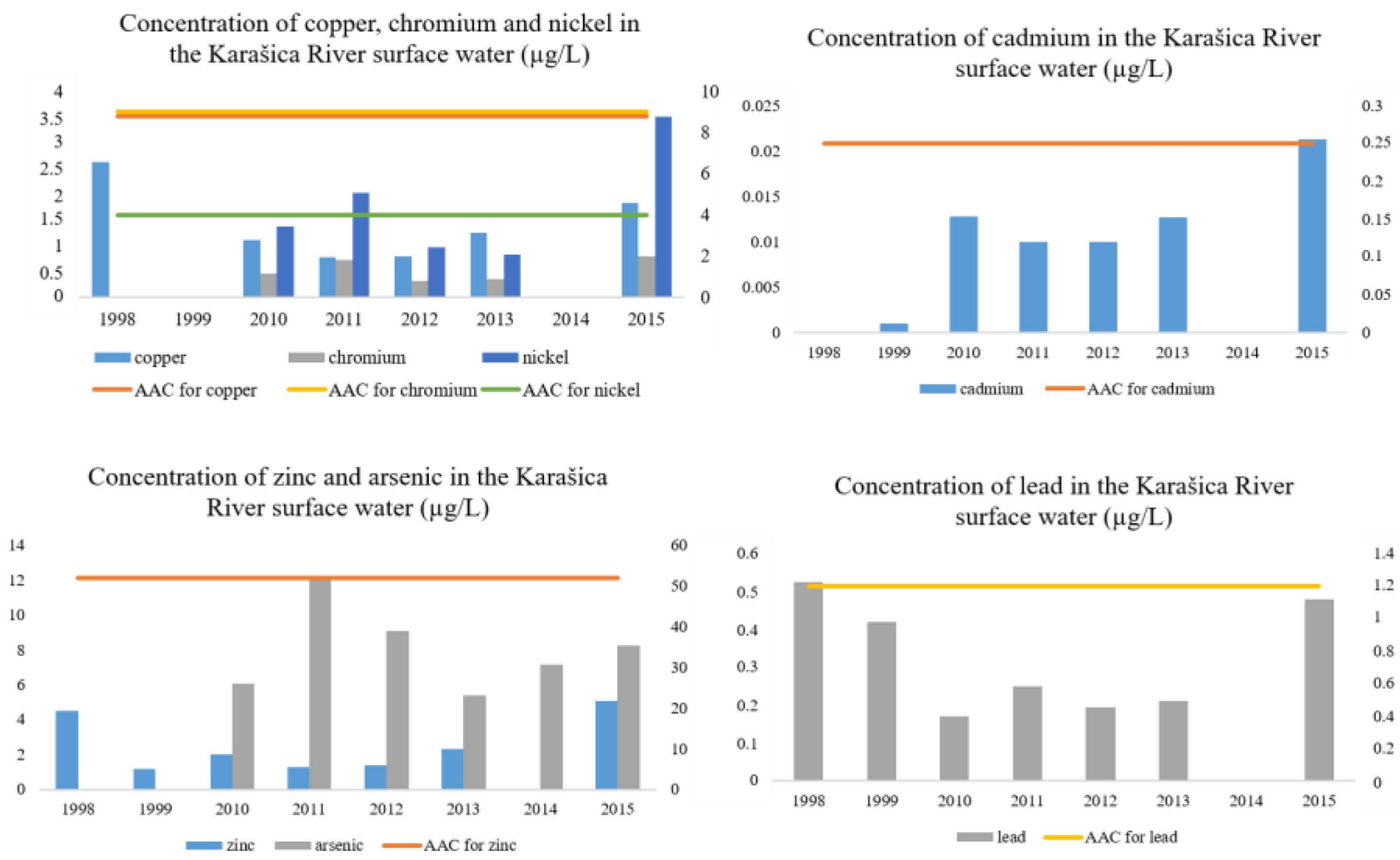

Concentration of manganese and iron in the Karašica River surface water $(\mu \mathrm{g} / \mathrm{L})$

Concentration of mercury in the Karašica River surface water $(\mu \mathrm{g} / \mathrm{L})$
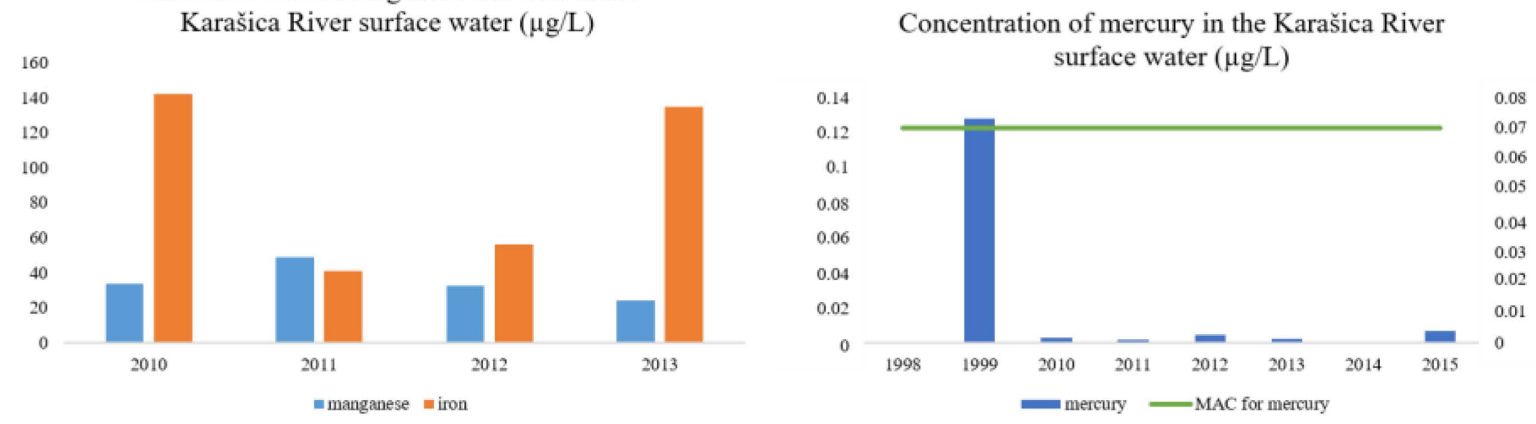

Figure 9. Average annual concentration of heavy metals in the Karašica River surface water. 

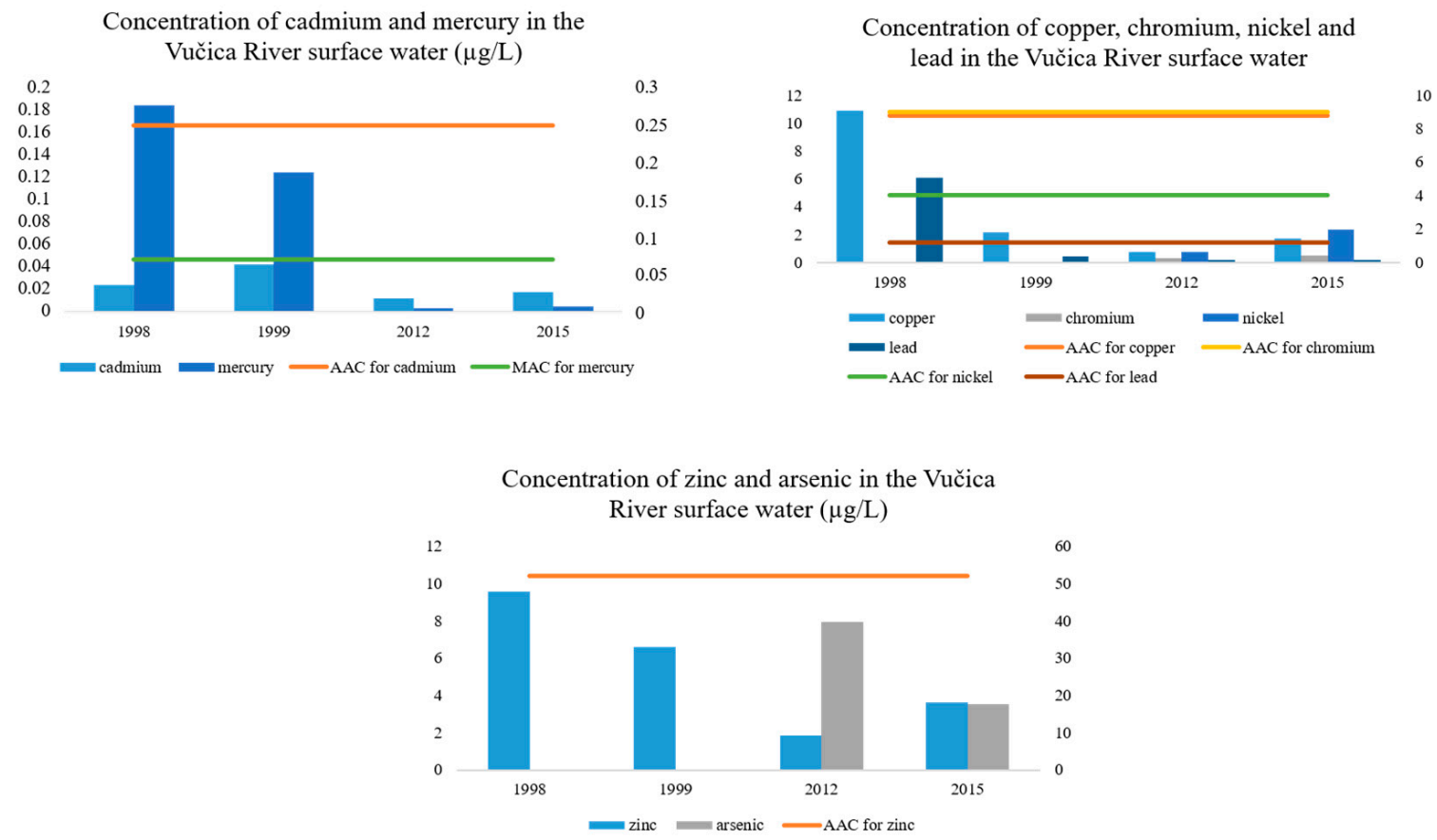

Figure 10. Average annual concentration of heavy metals in the Vučica River surface water.

Turgut (2000) obtained concentrations of heavy metals in surface water in Kücük Menderes River in Turkey, that mainly originated from pesticides applied on agricultural land. Concentration of the studied metals varied from not detected to $0.258 \mathrm{mg} / \mathrm{L}$, and the residues were low except for $\mathrm{Ni}, \mathrm{Cu}$, and $\mathrm{Zn} \mathrm{[57].} \mathrm{A} \mathrm{3-year} \mathrm{survey} \mathrm{of} \mathrm{Simeonov} \mathrm{et} \mathrm{al.} \mathrm{(2003),} \mathrm{conducted} \mathrm{in} \mathrm{the} \mathrm{major} \mathrm{Greek} \mathrm{river} \mathrm{systems}$ including main streams, tributaries and ditches, showed that the main source of heavy metals $(\mathrm{Pb}, \mathrm{Zn}$, Cd) is highly related to anthropogenic activities [15], what can be concluded from our investigation as well.

\section{Conclusions}

Based on the available data and according to The Decree on Water Quality Standards (Official Gazette 73/13), the quality of the surface water of the Karašica River can be described as good to moderate, and the quality of the surface water of the Vučica River as good to very good, depending on the parameter and year. The water quality regarding eutrophication can also be described as good and, in some cases, very good, while the water quality regarding heavy metals content can be described as good.

Obtained results confirm the need to keep the concentration of nitrogen and nitrates in surface water of this small catchment area under control, especially considering increasing trends of these nutrients which can lead to increasing environmental overload and to rapid development of eutrophication. Because of the high heavy metal toxicity and their involvement in biogeochemical processes, it is also necessary to keep their concentration under control. Water quality status considering $\mathrm{BOD}_{5}, \mathrm{COD}-\mathrm{Mn}$, orthophosphates and total $\mathrm{P}$ varies between good and very good, even on the sampling site 21012 situated in the vicinity of the distaff industry and does not show deterioration.

Further investments in wastewater treatment plants, reduction of excessive fertilisation (implementation of the Nitrate Directive), and agricultural development on the ecological basis are the driving forces in water quality improvement. In order to ensure an adequate enforcement of the afore said measures and to increase reliability of water quality categorisation, it is also necessary to continue to regular water quality monitoring and to increase the number of sampling sites along the river flow. The prerequisite for all of these activities is rising economic status of the region and the 
state in general. Analysis of water quality parameters observed in the period between 1998 and 2015, shows how slow the process of improvement is.

Acknowledgments: We are very grateful to the staff of Hrvatske vode, for their help with field and experimental research.

Author Contributions: Lidija Tadić conceived and designed the manuscript draft. Ana Amić analyzed the data and legal regulations, and wrote the paper with Lidija Tadić. Lidija Tadić revised the paper.

Conflicts of Interest: The authors declare no conflict of interest.

\section{Appendix A}

Table A1. Acidity (pH) of surface waters of the Karašica River from 1998 until 2015.

\begin{tabular}{|c|c|c|c|c|}
\hline Sampling Station & Year & Average & Min-Max & $50 \%$ \\
\hline \multirow{8}{*}{21019} & 2000 & 7.43 & $7.05-8.0$ & 7.31 \\
\hline & 2001 & 7.49 & $7.36-7.58$ & 7.51 \\
\hline & 2002 & 7.42 & $7.34-7.6$ & 7.36 \\
\hline & 2003 & 7.72 & $7.37-8.13$ & 7.75 \\
\hline & 2012 & 8 & $7.6-8.1$ & 8 \\
\hline & 2013 & 7.8 & $7.7-8$ & 7.8 \\
\hline & 2014 & 7.53 & $7.23-7.99$ & 7.45 \\
\hline & 2015 & 7.95 & $7.75-8.14$ & 7.95 \\
\hline \multirow{18}{*}{21012} & 1998 & 7.65 & $7.6-7.7$ & 7.65 \\
\hline & 1999 & 7.35 & $7.2-7.5$ & 7.35 \\
\hline & 2000 & 7.86 & $7.6-8.1$ & 7.86 \\
\hline & 2001 & 7.68 & $7.4-8.01$ & 7.66 \\
\hline & 2002 & 7.64 & $7.42-8$ & 7.56 \\
\hline & 2003 & 7.68 & $7.45-7.94$ & 7.69 \\
\hline & 2004 & 7.6 & $7.4-7.9$ & 7.6 \\
\hline & 2005 & 7.7 & $7.5-7.9$ & 7.7 \\
\hline & 2006 & 7.9 & $7.7-8$ & 7.9 \\
\hline & 2007 & 7.7 & $7.5-8$ & 7.7 \\
\hline & 2008 & 7.7 & $7.5-8$ & 7.7 \\
\hline & 2009 & 7.8 & $7.6-8$ & 7.8 \\
\hline & 2010 & 7.8 & $7.6-8$ & 7.9 \\
\hline & 2011 & 7.8 & $7.5-8.3$ & 7.8 \\
\hline & 2012 & 7.8 & $7.4-8.1$ & 7.8 \\
\hline & 2013 & 7.7 & $7.4-7.9$ & 7.7 \\
\hline & 2014 & 7.78 & $7.5-7.9$ & 7.8 \\
\hline & 2015 & 7.85 & $7.5-8.1$ & 7.9 \\
\hline \multirow{5}{*}{21021} & 1998 & 8.1 & $7.5-8.8$ & 8.15 \\
\hline & 1999 & 9.2 & 9.2 & 9.2 \\
\hline & 2012 & 7.8 & $7.8-7.9$ & 7.8 \\
\hline & 2013 & 7.6 & $7.4-7.8$ & 7.6 \\
\hline & 2015 & 7.7 & $7.45-7.93$ & 7.79 \\
\hline
\end{tabular}

Table A2. Acidity (pH) of surface waters of the Vučica River from 1998 until 2015.

\begin{tabular}{ccccc}
\hline Sampling Station & Year & Average & Min-Max & $\mathbf{5 0 \%}$ \\
\hline & 1998 & 7.9 & $7.5-8.3$ & 7.9 \\
21020 & 1999 & 7.7 & $7.1-8.3$ & 7.7 \\
& 2012 & 7.7 & $7.6-7.7$ & 7.7 \\
& 2013 & 7.7 & $7.4-7.9$ & 7.7 \\
& 2014 & 7.5 & $7.3-7.8$ & 7.51 \\
& 2015 & 7.8 & $7.7-8$ & 7.9 \\
\hline
\end{tabular}


Table A2. Cont.

\begin{tabular}{ccccc}
\hline Sampling Station & Year & Average & Min-Max & $\mathbf{5 0 \%}$ \\
\hline 1998 & 7.8 & $7.7-7.9$ & 7.8 \\
1999 & 7.4 & $7.2-7.6$ & 7.4 \\
2000 & 7.74 & $7.4-7.95$ & 7.81 \\
2001 & 7.53 & $7.1-7.86$ & 7.58 \\
2002 & 7.62 & $7.53-7.75$ & 7.61 \\
2003 & 7.8 & $7.72-8.04$ & 7.78 \\
2005 & 7.7 & $7.4-8$ & 7.7 \\
2006 & 7.6 & $8-10$ & 7.8 \\
2007 & 7.7 & $7.5-8$ & 7.7 \\
2008 & 7.7 & $7.2-8$ & 7.7 \\
& 2009 & 7.7 & $7.4-8$ & 7.7 \\
& 2010 & 7.8 & $7.5-7.8$ & 7.8 \\
& 2011 & 7.8 & $7.6-8$ & 7.8 \\
& 2012 & 7.9 & $7.7-8$ & 7.9 \\
& 2013 & 7.8 & $7.6-8.1$ & 7.85 \\
& 2014 & 7.84 & $7.6-8$ & 7.84 \\
\hline
\end{tabular}

Table A3. Water oxygenation (BOD 5 and $\mathrm{COD}-\mathrm{Mn}$ ) of the Karašica River surface water during the studied period (1998-2015).

\begin{tabular}{|c|c|c|c|c|c|c|c|}
\hline \multirow{2}{*}{ Sampling Station } & \multirow{2}{*}{ Year } & \multicolumn{3}{|c|}{$\mathrm{BOD}_{5}\left(\mathrm{mg} \mathrm{O} \mathrm{O}_{2} / \mathrm{L}\right)$} & \multicolumn{3}{|c|}{ COD-Mn $\left(\mathrm{mg} \mathrm{O}_{2} / \mathrm{L}\right)$} \\
\hline & & Average & Min-Max & $50 \%$ & Average & Min-Max & $50 \%$ \\
\hline \multirow{8}{*}{21019} & 2000 & 4.328 & $1.16-7.77$ & 4.19 & 8.208 & $6.66-9.77$ & 8.2 \\
\hline & 2001 & 16.22 & $3.03-40.3$ & 10.765 & 5.113 & $4.9-5.61$ & 4.97 \\
\hline & 2002 & 12.5 & $2.3-18.9$ & 14.4 & 8.093 & $6.4-8.77$ & 8.6 \\
\hline & 2003 & 10.65 & $2.4-27.9$ & 7.6 & 6.88 & $3.9-8.5$ & 7.2 \\
\hline & 2012 & 2.7 & $0.5-4.4$ & 3 & 5.2 & $3.4-6.3$ & 5.5 \\
\hline & 2013 & 1.9 & $1.1-2.8$ & 1.8 & 3.5 & $3.2-3.8$ & 3.5 \\
\hline & 2014 & 3.86 & $1.8-6.53$ & 3.56 & 9.625 & $4.3-13$ & 10.1 \\
\hline & 2015 & 3.37 & $1.4-5.53$ & 3.515 & 4.517 & $2.5-8.6$ & 4.35 \\
\hline \multirow{18}{*}{21012} & 1998 & 5.64 & $5.52-5.76$ & 5.64 & 4.09 & $3.38-4.8$ & 4.09 \\
\hline & 1999 & 5.135 & $3.24-7.03$ & 6.865 & - & - & 5.135 \\
\hline & 2000 & 2.11 & $1.61-2.71$ & 2.06 & 5.16 & $4.82-5.45$ & 5.18 \\
\hline & 2001 & 3.76 & $2.75-4.6$ & 3.85 & 4.30 & $2.59-4.98$ & 4.82 \\
\hline & 2002 & 3.67 & $0.7-7.39$ & 3.31 & 5.27 & $3.56-7.43$ & 5.045 \\
\hline & 2003 & 4.05 & $1.5-10.5$ & 3.2 & 4.13 & $3-4.7$ & 4.3 \\
\hline & 2004 & 3.4 & $1.7-8.7$ & 2.4 & 5.9 & $3.4-10.4$ & 5.3 \\
\hline & 2005 & 3.3 & $1.7-7.1$ & 2.9 & 5.4 & $2.4-7.4$ & 5.9 \\
\hline & 2006 & 3.2 & $0.4-6.5$ & 3 & 5.6 & $4.1-7.7$ & 5.4 \\
\hline & 2007 & 2.9 & $1.2-7.3$ & 2.8 & 5.7 & $2.9-8.7$ & 5.4 \\
\hline & 2008 & 3 & $0.7-7.4$ & 2.8 & 5 & $3.1-10$ & 3.8 \\
\hline & 2009 & 1.8 & $0.5-5$ & 1.5 & 4.4 & $2.5-7$ & 3.9 \\
\hline & 2010 & 2.1 & $1-4.7$ & 1.8 & 5.6 & $2.9-11.8$ & 4 \\
\hline & 2011 & 1.8 & $0.6-3.8$ & 1.6 & 3.9 & $2.2-8$ & 3.9 \\
\hline & 2012 & 2.9 & $0.8-5.1$ & 3 & 10 & 2-61 & 4.5 \\
\hline & 2013 & 3.2 & $0.8-8.1$ & 2.6 & 6.3 & $2.8-18.1$ & 4.6 \\
\hline & 2014 & 3.36 & $1.2-10.7$ & 2.2 & 5.69 & $2.2-14.6$ & 4.3 \\
\hline & 2015 & 3.65 & $1.1-9$ & 3.5 & 6.64 & $2.8-12.5$ & 5.5 \\
\hline \multirow{5}{*}{21021} & 1998 & 10.82 & $4.37-17.27$ & 10.82 & 7.625 & $6.72-8.53$ & 7.625 \\
\hline & 1999 & 2.49 & 2.49 & 2.94 & 8.94 & 8.94 & 8.94 \\
\hline & 2012 & 2.3 & $0.8-3.8$ & 2.1 & 4.6 & $4.2-5$ & 4.6 \\
\hline & 2013 & 1.8 & $1-2.8$ & 1.8 & 3.8 & $3.4-4.3$ & 3.8 \\
\hline & 2015 & 3.436 & $1.47-5.28$ & 3.505 & 4.875 & $3.1-7$ & 5.05 \\
\hline
\end{tabular}


Table A4. Water oxygenation ( $\mathrm{BOD}_{5}$ and $\left.\mathrm{COD}-\mathrm{Mn}\right)$ of the Vučica River surface water during the studied period (1998-2015).

\begin{tabular}{cccccccc}
\hline \multirow{2}{*}{$\begin{array}{c}\text { Sampling } \\
\text { Station }\end{array}$} & Year & \multicolumn{3}{c}{ BOD $_{\mathbf{5}}\left(\mathbf{m g} \mathbf{O}_{\mathbf{2}} / \mathrm{L}\right)$} & \multicolumn{3}{c}{ COD-Mn $\left(\mathbf{m g ~ O}_{\mathbf{2}} / \mathrm{L}\right)$} \\
\cline { 3 - 8 } & & Average & Min-Max & $\mathbf{5 0} \%$ & Average & Min-Max & $\mathbf{5 0} \%$ \\
\hline \multirow{4}{*}{21020} & 1998 & 2.461 & $1.03-2.62$ & 1.825 & 2.772 & $2.16-3.39$ & 2.775 \\
& 1999 & 1.72 & $1.67-1.77$ & 1.72 & 3.62 & $3.29-3.95$ & 3.62 \\
& 2012 & 2.6 & $1-5.3$ & 2.4 & 5.2 & $3.6-9.8$ & 4.2 \\
& 2013 & 2.6 & $1.6-3.5$ & 2.8 & 4.7 & $4.1-5.3$ & 4.7 \\
& 2014 & 5.433 & $3.1-7$ & 5.815 & 10.525 & $5.8-14.5$ & 10.9 \\
& 2015 & 3.575 & $1.3-7.5$ & 3.3 & 6.642 & $4.1-11$ & 6.3 \\
\hline \multirow{2}{*}{21007} & 1998 & 5.57 & $1.32-9.82$ & 5.57 & 3.015 & $2.56-3.47$ & 3.015 \\
& 1999 & 3.195 & $3.01-3.38$ & 3.195 & 6.04 & $5.45-6.63$ & 6.04 \\
& 2000 & 2.82 & $2.21-3.37$ & 2.85 & 5.175 & $4.03-6.24$ & 5.215 \\
& 2001 & 6.3575 & $3.68-9.15$ & 6.3 & 5.755 & $3.42-6.8$ & 6.4 \\
& 2002 & 4.8825 & $1.4-7.24$ & 5.445 & 7.2125 & $5.61-8.7$ & 7.27 \\
& 2003 & 5.55 & $1.9-14.9$ & 4.6 & 5.175 & $3.9-8$ & 4.5 \\
& 2004 & - & - & - & - & - & - \\
& 2005 & 3.7 & $0.3-11.5$ & 3.2 & 6.1 & $3.5-11.5$ & 5.3 \\
& 2006 & 3.5 & $0.7-5.6$ & 3.3 & 5.1 & $3.9-6.2$ & 4.8 \\
& 2007 & 4.4 & $2.4-6.6$ & 4.2 & 5.5 & $4.2-7.3$ & 5.4 \\
& 2008 & 3.9 & $1.5-7.3$ & 3.8 & 5.6 & $2.9-7.6$ & 5.4 \\
& 2009 & 3.5 & $1.3-5.8$ & 3.5 & 4.8 & $3.4-6.1$ & 4.6 \\
& 2010 & 4.5 & $1.9-8.2$ & 4.2 & 6.5 & $3.7-11.2$ & 5.6
\end{tabular}

Table A5. Content of nitrogen compounds (nitrates and total nitrogen) in the Karašica River surface water during the studied period (1998-2015).

\begin{tabular}{cccccccc}
\hline \multirow{2}{*}{$\begin{array}{c}\text { Sampling } \\
\text { Station }\end{array}$} & Year & \multicolumn{3}{c}{ Nitrates $(\mathbf{m g}$ N/L) } & \multicolumn{3}{c}{ Total Nitrogen (mg N/L) } \\
\cline { 3 - 7 } & & Average & Min-Max & $\mathbf{5 0 \%}$ & Average & Min-Max & $\mathbf{5 0 \%}$ \\
\hline & 2000 & 0.735 & $0.678-0.904$ & 0.678 & 3.26 & $2.568-4.239$ & 3.112 \\
& 2001 & 1.186 & $0.904-1.356$ & 1.243 & 1.94 & $1.358-2.418$ & 2.0005 \\
& 2002 & 1.187 & $0.452-2.26$ & 1.017 & 3.01 & $2.476-3.336$ & 3.1185 \\
21019 & 2003 & 0.734 & $0.226-2.712$ & 0.452 & 2.09 & $0.97-3.391$ & 1.8475 \\
& 2012 & 0.264 & $0.1-0.813$ & 0.1 & 0.71 & $0.383-1.66$ & 0.5078 \\
& 2013 & $<0.701$ & $<0.701$ & $<0.701$ & 0.57 & $0.319-0.93$ & 0.5234 \\
& 2014 & 0.64 & $0.249-1.06$ & 0.63 & 0.88 & $0.54-1.2$ & 0.90275 \\
& 2015 & 0.686 & $0.13-1.67$ & 0.405 & 1.05 & $0.436-2.088$ & 0.7975 \\
\hline
\end{tabular}


Table A5. Cont.

\begin{tabular}{cccccccc}
\hline \multirow{2}{*}{$\begin{array}{c}\text { Sampling } \\
\text { Station }\end{array}$} & Year & \multicolumn{3}{c}{ Nitrates (mg N/L) } & \multicolumn{2}{c}{ Total Nitrogen (mg N/L) } \\
\cline { 3 - 7 } & & Average & Min-Max & $\mathbf{5 0 \%}$ & Average & Min-Max & $\mathbf{5 0 \%}$ \\
\hline & 1998 & - & - & - & - & - & - \\
& 1999 & - & - & - & - & - & - \\
& 2000 & 0.6215 & $0.452-0.904$ & 0.565 & 1.96 & $1.554-2.433$ & 1.9265 \\
& 2001 & 0.678 & $0.452-0.904$ & 0.678 & 1.25025 & $0.77-1.596$ & 1.3175 \\
& 2002 & 0.904 & $0.678-1.13$ & 0.904 & 1.525 & $0.877-2.35$ & 1.4365 \\
& 2003 & 0.6215 & $0.226-1.356$ & 0.339 & 1.0948 & $0.746-1.886$ & 0.8695 \\
21012 & 2004 & 3.2142 & $2.712-4.068$ & 3.164 & 3.8081 & $3.256-4.957$ & 3.581 \\
& 2005 & 1.4564 & $0.226-4.068$ & 1.582 & 1.7171 & $0.402-4.263$ & 1.745 \\
& 2006 & 0.904 & $0.226-2.26$ & 0.678 & 1.2553 & $0.382-2.52$ & 1.249 \\
& 2007 & 0.7684 & $0.226-1.808$ & 0.565 & 1.0198 & $0.385-2.348$ & 0.818 \\
& 2008 & 1.1978 & $0.226-2.712$ & 0.791 & 1.4556 & $0.5-3.019$ & 0.9135 \\
& 2009 & 0.6127 & $0.01-4.5$ & 0.17 & 1.1223 & $0.43-5.21$ & 0.63 \\
& 2010 & 1.5158 & $0.02-4.13$ & 1.195 & 1.9958 & $0.28-4.5$ & 1.755 \\
& 2011 & 0.5496 & $0.01-1.62$ & 0.375 & 0.9708 & $0.31-1.99$ & 0.765 \\
& 2012 & 0.7255 & $0.1-4.6$ & 0.36 & 1.2982 & $0.4-5.56$ & 0.84 \\
& 2013 & 1.2444 & $0.1-2.76$ & 1.28 & 1.73 & $0.31-3.34$ & 1.76 \\
& 2014 & 1.015 & $0.14-2.95$ & 0.885 & 1.4843 & $0.5-3.09$ & 1.42 \\
& 2015 & 1.0475 & $0.08-2.46$ & 0.725 & 1.4942 & $0.35-2.95$ & 1.115 \\
\hline
\end{tabular}

Table A6. Content of nitrogen compounds (nitrates and total nitrogen) in the Vučica River surface water during the studied period (1998-2015).

\begin{tabular}{cccccccc}
\hline \multirow{2}{*}{$\begin{array}{c}\text { Sampling } \\
\text { Station }\end{array}$} & Year & \multicolumn{3}{c}{ Nitrates $\mathbf{( m g}$ N/L) } & \multicolumn{2}{c}{ Total Nitrogen (mg N/L) } \\
\cline { 2 - 7 } & & Average & Min-Max & $\mathbf{5 0} \%$ & Average & Min-Max & $\mathbf{5 0 \%}$ \\
\hline \multirow{2}{*}{21020} & 1998 & 0.34 & $0.23-0.45$ & 0.34 & - & - & - \\
& 1999 & 0.44 & $0.43-0.45$ & 0.45 & - & - & - \\
& 2012 & 0.282 & $0.1-0.626$ & 0.1862 & 0.776 & $0.422-1.124$ & 1.313 \\
& 2013 & 0.701 & $0.701-0.746$ & 0.701 & 1.302 & $0.8325-1.666$ & 1.355 \\
& 2014 & 0.897 & $0.357-1.69$ & 0.77 & 1.669 & $1.233-2.414$ & 1.5145 \\
& 2015 & 1.25 & $0.39-2.94$ & 0.84 & 1.887 & $0.94-3.56$ & 1.565 \\
\hline & 1998 & - & - & - & - & - & - \\
& 1999 & - & - & - & - & - & - \\
& 2000 & 0.622 & $0.452-0.904$ & 0.565 & 1.8953 & $1.263-2.455$ & 1.9315 \\
& 2001 & 0.791 & $0.678-0.904$ & 0.791 & 1.3593 & 1.124 & 1.3735 \\
& 2002 & 1.017 & $0.678-1.808$ & 0.791 & 1.894 & $1.395-2.175$ & 2.003 \\
& 2003 & 0.8193 & $0.452-1.13$ & 0.791 & 1.5448 & $1.017-2.128$ & 1.504 \\
& 2004 & - & - & - & - & - & - \\
& 2005 & 1.3309 & $0.452-2.26$ & 1.808 & 1.6803 & $0.631-2.428$ & 2.007 \\
& 2006 & 0.9266 & $0.226-2.26$ & 0.791 & 1.3442 & $0.371-2.73$ & 1.184 \\
& 2007 & 0.9492 & $0.452-2.26$ & 0.791 & 1.2525 & $0.53-2.736$ & 1.0545 \\
& 2008 & 1.4238 & $0.452-2.712$ & 1.356 & 1.7635 & $0.547-3.167$ & 1.63 \\
& 2009 & 0.5055 & $0.157-1.043$ & 0.366 & 1.1845 & $0.46-2.812$ & 0.729 \\
& 2010 & 1.3759 & $0.44-3.79$ & 1.236 & 1.8558 & $0.876-4.074$ & 1.637
\end{tabular}


Table A7. Content of phosphorus compounds (orthophosphates and total phosphorus) in the Karašica River surface water during the studied period (1998-2015).

\begin{tabular}{|c|c|c|c|c|c|c|c|}
\hline \multirow{2}{*}{$\begin{array}{l}\text { Sampling } \\
\text { Station }\end{array}$} & \multirow{2}{*}{ Year } & \multicolumn{3}{|c|}{ Orthophosphates (mg P/L) } & \multicolumn{3}{|c|}{ Total Phosphorus (mg P/L) } \\
\hline & & Average & Min-Max & $50 \%$ & Average & Min-Max & $50 \%$ \\
\hline \multirow{8}{*}{21019} & 2000 & 0.378 & $0.221-0.561$ & 0.3655 & 0.974 & $0.917-1.102$ & 0.9385 \\
\hline & 2001 & 0.366 & $0.103-0.728$ & 0.317 & 0.524 & $0.196-0.834$ & 0.533 \\
\hline & 2002 & 0.257 & $0.219-0.314$ & 0.248 & 0.495 & $0.397-0.568$ & 0.5075 \\
\hline & 2003 & 0.333 & $0.043-0.804$ & 0.2905 & 0.535 & $0.14-0.982$ & 0.5225 \\
\hline & 2012 & 0.0623 & $0.045-0.092$ & 0.057 & 0.0863 & $0.06-0.12$ & 0.085 \\
\hline & 2013 & 0.0312 & $0.027-0.055$ & 0.0282 & 0.0173 & $0.09-0.12$ & 0.105 \\
\hline & 2014 & 0.097 & $0.074-0.143$ & 0.0855 & 0.185 & $0.1-0.28$ & 0.18 \\
\hline & 2015 & 0.4075 & $0.024-0.067$ & 0.039 & 0.0825 & $0.05-0.14$ & 0.08 \\
\hline \multirow{18}{*}{21012} & 1998 & - & - & - & - & - & - \\
\hline & 1999 & - & - & - & - & - & - \\
\hline & 2000 & 0.06725 & $0.043-0.117$ & 0.0545 & 0.237 & $0.168-0.374$ & 0.203 \\
\hline & 2001 & 0.1655 & $0.068-0.323$ & 0.1355 & 0.2645 & $0.131-0.498$ & 0.2145 \\
\hline & 2002 & 0.1435 & $0.082-0.193$ & 0.1435 & 0.303 & $0.112-0.427$ & 0.3365 \\
\hline & 2003 & 0.09925 & $0.015-0.214$ & 0.0765 & 0.168 & $0.041-0.272$ & 0.161 \\
\hline & 2004 & 0.1333 & $0.073-0.23$ & 0.115 & 0.256 & $0.124-0.478$ & 0.214 \\
\hline & 2005 & 0.0959 & $0.071-0.142$ & 0.092 & 0.1459 & $0.108-0.21$ & 0.133 \\
\hline & 2006 & 0.3605 & $0.027-1.433$ & 0.122 & 0.6402 & $0.059-2.385$ & 0.2245 \\
\hline & 2007 & 0.1043 & $0.064-0.163$ & 0.109 & 0.192 & $0.115-0.283$ & 0.1795 \\
\hline & 2008 & 0.0756 & $0.041-0.138$ & 0.0825 & 0.1596 & $0.068-0.532$ & 0.1875 \\
\hline & 2009 & 0.0522 & $0.018-0.159$ & 0.034 & 0.1412 & $0.055-0.276$ & 0.117 \\
\hline & 2010 & 0.121 & $0.023-0.309$ & 0.101 & 0.2292 & $0.092-0.453$ & 0.1665 \\
\hline & 2011 & 0.0584 & $0.016-0.108$ & 0.0592 & 0.1721 & $0.04-0.52$ & 0.149 \\
\hline & 2012 & 0.0827 & $0.006-0.265$ & 0.051 & 0.2082 & $0.072-0.508$ & 0.143 \\
\hline & 2013 & 8.6376 & $0.051-77$ & 0.096 & 17.138 & $0.101-152$ & 0.176 \\
\hline & 2014 & 0.1127 & $0.025-0.319$ & 0.1 & 0.2008 & $0.109-0.358$ & 0.1855 \\
\hline & 2015 & 0.09825 & $0.031-0.2$ & 0.0935 & 0.2793 & $0.104-0.552$ & 0.26 \\
\hline \multirow{5}{*}{21021} & 1998 & - & - & - & - & - & - \\
\hline & 1999 & - & - & - & - & - & - \\
\hline & 2012 & 0.108 & $0.08-0.138$ & 0.1 & 0.1703 & $0.12-0.29$ & 0.156 \\
\hline & 2013 & 0.0655 & $0.035-0.095$ & 0.066 & 0.16 & $0.08-0.31$ & 0.125 \\
\hline & 2015 & 0.0902 & $0.034-0.158$ & 0.076 & 0.2373 & $0.08-0.8$ & 0.11 \\
\hline
\end{tabular}

Table A8. Content of phosphorus compounds (orthophosphates and total phosphorus) in the Vučica River surface water during the studied period (1998-2015).

\begin{tabular}{cccccccc}
\hline \multirow{2}{*}{$\begin{array}{c}\text { Sampling } \\
\text { Station }\end{array}$} & Year & \multicolumn{3}{c}{ Orthophosphates (mg P/L) } & \multicolumn{2}{c}{ Total Phosphorus (mg P/L) } \\
\cline { 3 - 8 } & & Average & Min-Max & $\mathbf{5 0 \%}$ & Average & Min-Max & $\mathbf{9 0 \%}$ \\
\hline \multirow{4}{*}{21020} & 1998 & - & - & - & - & - & - \\
& 1999 & - & - & - & - & - & - \\
& 2012. & 0.053 & $0.041-0.073$ & 0.0465 & 0.0733 & $0.06-0.1$ & 0.07 \\
& 2013 & 0.0362 & $0.027-0.062$ & 0.0348 & 0.14 & $0.05-0.28$ & 0.115 \\
& 2014 & 0.1345 & $0.06-0.264$ & 0.107 & 0.1825 & $0.08-0.35$ & 0.15 \\
& 2015 & 0.0482 & $0.005-0.106$ & 0.037 & 0.2456 & $0.1-0.562$ & 0.234 \\
\hline
\end{tabular}


Table A8. Cont.

\begin{tabular}{cccccccc}
\hline \multirow{2}{*}{$\begin{array}{c}\text { Sampling } \\
\text { Station }\end{array}$} & Year & \multicolumn{2}{c}{ Orthophosphates (mg P/L) } & \multicolumn{2}{c}{ Total Phosphorus (mg P/L) } \\
\cline { 3 - 7 } & & Average & Min-Max & $\mathbf{5 0 \%}$ & Average & Min-Max & $\mathbf{9 0 \%}$ \\
\hline & 1998 & - & - & - & - & - & - \\
& 1999 & - & - & - & - & - & - \\
& 2000 & 0.06575 & $0.027-0.101$ & 0.0675 & 0.18975 & $0.112-0.281$ & 0.183 \\
& 2001 & 0.15275 & $0.066-0.362$ & 0.0915 & 0.234 & $0.142-0.401$ & 0.1965 \\
& 2002 & 0.2275 & $0.092-0.45$ & 0.184 & 0.5175 & $0.281-0.871$ & 0.459 \\
& 2003 & 0.08413 & $0.051-0.138$ & 0.0685 & 0.1678 & $0.105-0.281$ & 0.0157 \\
& 2004 & - & - & - & - & - & - \\
& 2005 & 0.2352 & $0.068-1.398$ & 0.089 & 0.4029 & $0.129-2.417$ & 0.138 \\
& 2006 & 0.2706 & $0.034-1.067$ & 0.089 & 0.5584 & $0.057-2.281$ & 0.18 \\
& 2007 & 0.0956 & $0.059-0.161$ & 0.0835 & 0.1822 & $0.103-0.325$ & 0.1445 \\
& 2008 & 0.0796 & $0.043-0.156$ & 0.0695 & 0.1608 & $0.085-0.258$ & 0.1525 \\
& 2009 & 0.0747 & $0.022-0.138$ & 0.078 & 0.1605 & $0.05-0.288$ & 0.161 \\
& 2010 & 0.1187 & $0.043-0.288$ & 0.092 & 0.2253 & $0.089-0.531$ & 0.161 \\
& 2011 & 0.0524 & $0.018-0.092$ & 0.0485 & 0.1057 & $0.04-0.189$ & 0.096 \\
& 2012 & 0.0506 & $0.01-0.111$ & 0.0465 & 0.1542 & $0.073-0.222$ & 0.159 \\
& 2013 & 0.0749 & $0.023-0.192$ & 0.065 & 0.2628 & $0.084-0.572$ & 0.149 \\
& 2014 & 0.07592 & $0.021-0.154$ & 0.0775 & 0.238 & $0.107-0.604$ & 0.196 \\
& 2015 & 0.04942 & $0.019-0.09$ & 0.045 & 0.1871 & $0.05-0.72$ & 0.09 \\
\hline
\end{tabular}


Table A9. Average annual concentration of heavy metals (orthophosphates and total phosphorus) in Karašica and Vučica rivers surface water during the studied period (1998-2015).

\begin{tabular}{|c|c|c|c|c|c|c|c|c|c|c|c|}
\hline $\begin{array}{l}\text { Sampling } \\
\text { Station }\end{array}$ & Year & $\begin{array}{c}\text { Copper } \\
(\mu \mathrm{g} / \mathrm{L})\end{array}$ & $\begin{array}{c}\text { Zink } \\
(\mu \mathrm{g} / \mathrm{L})\end{array}$ & $\begin{array}{c}\text { Cadmium } \\
(\mu \mathrm{g} / \mathrm{L})\end{array}$ & $\begin{array}{c}\text { Chromium } \\
(\mu \mathrm{g} / \mathrm{L})\end{array}$ & $\begin{array}{c}\text { Nickel } \\
(\mu \mathrm{g} / \mathrm{L})\end{array}$ & $\begin{array}{c}\text { Lead } \\
(\mu \mathrm{g} / \mathrm{L})\end{array}$ & $\begin{array}{c}\text { Mercury } \\
(\mu \mathrm{g} / \mathrm{L})\end{array}$ & $\begin{array}{c}\text { Arsenic } \\
(\mu \mathrm{g} / \mathrm{L})\end{array}$ & $\begin{array}{c}\text { Manganese } \\
(\mu \mathrm{g} / \mathrm{L})\end{array}$ & Iron $(\mu \mathrm{g} / \mathrm{L})$ \\
\hline \multicolumn{12}{|c|}{ Karašica River } \\
\hline \multirow{6}{*}{21012} & 2010 & 1.1162 & 1.9862 & 0.01275 & 0.4561 & 1.3809 & 0.1714 & 0.0027 & 6.0716 & 33.6216 & 142.3334 \\
\hline & 2011 & 0.7774 & 1.3018 & 0.01 & 0.7228 & 2.0334 & 0.2494 & $<0.002$ & 12.134 & 48.96 & 41.22 \\
\hline & 2012 & 0.7878 & 1.3904 & $<0.01$ & 0.3096 & 0.9642 & 0.1946 & 0.0044 & 9.0872 & 32.6112 & 56.2824 \\
\hline & 2013 & 1.2466 & 2.3356 & 0.01267 & 0.3596 & 0.832 & 0.212 & 0.0023 & 5.4053 & 24.388 & 134.9863 \\
\hline & 2014 & - & - & - & - & - & - & - & 7.1415 & - & - \\
\hline & 2015 & 1.8346 & 5.0742 & 0.02125 & 0.8005 & 3.5083 & 0.4805 & 0.00678 & 8.2646 & - & - \\
\hline 21021 & 2015 & - & - & - & - & - & - & - & 8.4242 & - & - \\
\hline \multicolumn{12}{|c|}{ Vučica River } \\
\hline 21020 & 2015 & 1.6865 & 3.6349 & 0.01783 & 0.5012 & 2.3447 & 0.20142 & 0.00456 & 3.5463 & - & - \\
\hline 21007 & 2012 & 0.7535 & 1.8649 & 0.0119 & 0.2785 & 0.7699 & 0.18767 & 0.003425 & 7.9697 & 16.2846 & 29.1988 \\
\hline
\end{tabular}


Table A10. Assessment of the water quality of Karašica and Vučica rivers for the year 2015 [21]; every parameter is marked with adequate colour depending on determined water quality.

\begin{tabular}{|c|c|c|c|c|}
\hline Sampling Station & $\begin{array}{c}\text { Physical-Chemical } \\
\text { Parameters }\end{array}$ & Specific Pollutants & $\begin{array}{l}\text { Ecological } \\
\text { Condition }\end{array}$ & $\begin{array}{c}\text { Assessment } \\
\text { Reliability }\end{array}$ \\
\hline 21007 & & & & Medium \\
\hline 21012 & & & & Medium \\
\hline 21019 & & & & Medium \\
\hline 21020 & & & & Medium \\
\hline
\end{tabular}

Colour code: $($ Blue $)=$ very good condition; $($ Green $)=$ good condition; $($ Yellow $)=$ moderate condition; $($ Red $)=$ bad condition .

\section{References}

1. Voća, N.; Kučar Dragičević, S.; Zovko, M.; Mesić, H. Izvješće o Stanju Okoliša u Republici Hrvatskoj za Razdoblje 2005-2008; Agencija za zaštitu okoliša: Zagreb, Croatia, 2012; pp. 223-236; ISBN 978-953-7582-07-4.

2. Skaggs, R.W.; Brevé, M.A.; Gilliam, J.W. Hydrologic and water quality impacts of agricultural drainage. Crit. Rev. Environ. Sci. Technol. 1994, 24, 1-32. [CrossRef]

3. Azam, F.; Mulvaney, R.L.; Simmons, F.W. Effects of ammonium and nitrate on mineralization of nitrogen from leguminous residues. Biol. Fertil. Soils 1995, 20, 49-52. [CrossRef]

4. Bernhard, A. The nitrogen cycle: Processes, players, and human impact. Nat. Educ. Knowl. 2010, 3, 25.

5. Blann, K.L.; Anderson, J.L.; Sands, G.R.; Vondracek, B. Effects of agricultural drainage on aquatic ecosystems: A review. Crit. Rev. Environ. Sci. Technol. 2009, 39, 909-1001. [CrossRef]

6. Lončarić, Z.; Rastija, D.; Baličević, R.; Karalić, K.; Popović, B.; Ivezić, V. Plodnost i Opterećenost Tala u Pograničnome Području, 1st ed.; Faculty of Agriculture, Josip Juraj Strosmayer University of Osijek: Osijek, Croatia, 2014; pp. 26-34; ISBN 978-953-7871-16-1.

7. Gupta, S.K.; Gupta, R.C.; Gupta, A.B.; Seth, A.K.; Bassin, J.K.; Gupta, A. Recurrent acute respiratory tract infections in areas with high nitrate concentrations in drinking water. Environ. Health Perspect. 2000, 108, 363-366. [CrossRef] [PubMed]

8. Kramer, M.H.; Herwaldt, B.L.; Craun, G.F.; Calderon, R.L.; Juranek, D.D. Surveillance of waterborne-disease outbreaks-United States, 1993-1994. MMWR CDC Surveill. Summ. 1996, 45, 1-33.

9. Fan, A.M.; Steinberg, V.E. Health implications of nitrate and nitrite in drinking water: An update on methemoglobinemia occurrence and reproductive and developmental toxicity. Regul. Toxicol. Pharmacol. 1996, 23, 35-43. [CrossRef] [PubMed]

10. Gupta, S.K.; Gupta, R.C.; Seth, A.K.; Gupta, A.B.; Bassin, J.K.; Gupta, A. Methaemoglobinaemia in areas with high nitrate concentration in drinking water. Natl. Med. J. India 2000, 13, 58-61. [PubMed]

11. Wolfe, A.H.; Patz, J.A. Reactive nitrogen and human health: Acute and long-term implications. AMBIO 2002, 31, 120-125. [CrossRef] [PubMed]

12. Nitrates and Nitrites in Drinking Water. Background Document for Development of WHO Guidelines for Drinking Water Quality. Available online: http:/ /www.who.int/water_sanitation_health/dwq/chemicals/ nitratenitrite2ndadd.pdf (accessed on 21 May 2017).

13. Grgić, P. Utjecaj Poljoprivrednih Aktivnosti na Okoliš. Graduate Thesis, Faculty of Agriculture, Josip Juraj Strossmayer University of Osijek, Osijek, Croatia, 2014.

14. Simeonov, V.; Stratis, J.A.; Samara, C.; Zachariadis, G.; Voutsa, D.; Anthemidis, A.; Sofoniou, M.; Kouimtzis, Th. Assessment of the surface water quality in Northern Greece. Water Res. 2003, 37, 4119-4124. [CrossRef]

15. Tong, S.T.Y.; Chen, W. Modelling the relationship between land and surface water quality. J. Environ. Manag. 2002, 66, 377-393. [CrossRef]

16. Ouyang, Y. Evaluation of river water quality monitoring stations by principle component analysis. Water Res. 2005, 39, 2621-2635. [CrossRef] [PubMed]

17. Dragun, Z.; Kapetanović, D.; Raspor, B.; Teskeredžić, E. Water quality of medium size watercourse under baseflow conditions: The case study of river Sutla in Croatia. AMBIO 2011, 40, 391-407. [CrossRef] [PubMed]

18. Munjko, I.; Lovrić, E.; Jovinac, R. Eutrofne soli u slivu rijeka "Karašica-Vučica” sa posebnim osvrtom na problem nitrata. CJF 1980, 35, 101-105. 
19. Vidaček, Ž.; Sraka, M.; Čoga, L.; Mihelić, A. Nitrati, teški metali i herbicid u tlu i vodama sliva Karašica-Vučica. Am. Chem. Soc. 1999, 44, 143-150.

20. Jerković, M.; Sokáč, M.; Tadić, L. Analysis of the effects of a wastewater treatment plant failure on the Drava River water quality. e-GFOS 2016, 7, 57-65.

21. The Water Management Plan 2016-2021 (in Croatian). Available online: http://www.voda.hr/sites/default/ files/planupravljanjavodnimpodrucjima2016.-2020.pdf (accessed on 19 April 2017).

22. Nadilo, B. Tekla voda Karašica. Građevinar 2014, 66, 164-174.

23. Tadić, L. Analiza Indikatora Relevantnih za Održivo Gospodarenje Vodama Sliva Karašice i Vučice; Građevinski fakultet: Zagreb, Croatia, 2001; pp. 26-56; ISBN 953-6962-03-9.

24. Official Gazette (73/13): The Decree on Water Quality Standards in Croatian; Narodne Novine: Zagreb, Croatia, 2013.

25. Official Gazette (78/15): The Decree on Changes and Additions to the Decree on Water Quality Standards in Croatian; Narodne Novine: Zagreb, Croatia, 2015.

26. Istraživanje Vode. Program GLOBE-Priručnik za Mjerenja. Available online: http://globe.pomsk.hr/ / prirucnik/voda.PDF (accessed on 21 May 2017).

27. Gvozdić, V.; Brana, J.; Malatesti, N.; Roland, D. Principal component analysis of surface water quality data of the River Drava in eastern Croatia (24 year survey). J. Hydroinform. 2012, 14, 1051-1060. [CrossRef]

28. Abu, G.O.; Egenonu, C. The current pollution status of the new Calabar river in the Niger Delta region of Southern Nigeria: A survey of antibiogram profiles of its bacterial isolates. Afr. J. Environ. Sci. Technol. 2008, 2, 134-141.

29. Eisakhani, M.; Malakahmad, A. Water Quality Assessment of Bertam River and its Tributaries in Cameron Highlands, Malaysia. World Appl. Sci. J. 2009, 7, 769-776.

30. Chau, K.W.; Jiang, Y.W. Three-dimensional pollutant transport model for the Pearl River Estuary. Water Res. 2002, 36, 2029-2039. [CrossRef]

31. Živadinović, I.; Ilijević, K.; Gržetić, I.; Popović, A. Long term changes in the eco-chemical status of the Danube River in the region of Serbia. J. Serb. Chem. Soc. 2010, 75, 1125-1148. [CrossRef]

32. Wakawa, R.J.; Uzairu, A.; Kagbu, J.A.; Balarabe, M.L. Impact assessment of effluent discharge on physico-chemical parameters and some heavy metal concentrations in surface water of River Challawa Kano, Nigeria. Afr. J. Pure Appl. Chem. 2008, 2, 100-106.

33. Robson, M.; Spence, K.; Beech, L. Stream quality in a small urbanized catchment. Sci. Total Environ. 2006, 357, 194-207. [CrossRef] [PubMed]

34. Osibanjo, O.; Daso, A.P.; Gbadebo, A.M. The impact of industries on surface water quality of River Ona and River Alaro in Oluyole Industrial Estate, Ibadan, Nigeria. Afr J Biotechnol 2011, 10, 696-702.

35. Sofilic, T. Ekotoksikologija. Available online: http://bib.irb.hr/datoteka/743709.Tahir_Sofilic_ EKOTOKSIKOLOGIJA.pdf (accessed on 20 April 2017).

36. Serbian Environmental Protection Agency (SEPA). National Report on the State of the Environment; SEPA: Beograd, Serbia, 2008.

37. Babović, N.; Marković, D.; Dimitrijević, V.; Marković, D. Some indicators of water quality of the Tamiš River. Chem. Ind. Chem. Eng. Q. 2011, 17, 107-115. [CrossRef]

38. Globevnik, L.; Pintar, M.; Bremec, U. Cross compliance of the water framework and nitrate directives in Slovenia. Acta Agric. Slov. 2006, 87, 69-78.

39. Neal, C.; Jarvie, H.P.; Neal, M.; Hill, L.; Wickham, H. Nitrate concentrations in river waters of the upper Thames and its tributaries. Sci. Total Environ. 2006, 365, 15-32. [CrossRef] [PubMed]

40. Van Grinsvena, H.J.M.; Tiktaka, A.; Rougoorb, C.W. Evaluation of the Dutch implementation of the nitrates directive, the water framework directive and the national emission ceilings directive. NJAS Wagen. J. Life Sci. 2016, 78, 69-84. [CrossRef]

41. Jarvie, H.P.; Whitton, B.A.; Neal, C. Nitrogen and phosphorus in east coast British rivers: Speciation, sources and biological significance. Sci. Total Environ. 1998, 210-211, 79-109. [CrossRef]

42. The Nitrates Directive (Consolidated); Legal Name: Council Directive 91/676/EEC of 12 December 1991 Concerning the Protection of Waters against Pollution Caused by Nitrates from Agricultural Sources as Amended by Regulations 1882/2003/EC and 1137/2008/EC; Council of the European Union: Brussels, Belgium, 1991.

43. Judova, P.; Jansky, B. Water quality in rural areas of the Czech Republic: Key study Slapanka River catchment. Limnologica 2005, 35, 160-168. [CrossRef] 
44. Ntislidou, Ch.; Basdeki, A.; Papacharalampou, Ch.; Albanakis, K.; Lazaridou, M.; Voudouris, K. Ecological Water Quality and Management at a River Basin Kosynthos in June 2011. In Ecological Water Quality-Water Treatment and Reuse; Chapter 2; Voudouris, K., Ed.; InTech: Rijeka, Croatia, 2012. [CrossRef]

45. Iqbal, M.; Sajjad, H.; Bhat, F.A.; Ahmad, I. Monitoring of Water Quality Parameters in Upper and Lower Reaches of Dudhganga Catchment, India. In Perspectives in Water Pollution; Chapter 5; Ahmad, I., Ahmad Dar, M., Eds.; InTech: Rijeka, Croatia, 2013. [CrossRef]

46. Xu, E.; Zhang, H. Aggregating land use quantity and intensity to linkwater quality in upper catchment of Miyun Reservoir. Ecol. Indic. 2016, 66, 329-339. [CrossRef]

47. Crossman, J.; Whitehead, P.G.; Futter, M.N.; Jin, L.; Shahgedanova, M.; Castellazzi, M.; Wade, A.J. The interactive responses of water quality and hydrology to changes in multiple stressors, and implications for the long-term effective management of phosphorus. Sci. Total Environ. 2014, 468-469, 1255-1266. [CrossRef] [PubMed]

48. Chardon, W.J.; Schoumans, O.F. Soil texture effects on the transport of phosphorus from agricultural land in river deltas of Northern Belgium, the Netherlands and North-West Germany. Soil Use Manag. 2007, 23, 16-24. [CrossRef]

49. Gvozdić, V.; Brana, J.; Orešković, K.; Puntarić, D.; Vidosavljević, D.; Jergović, M.; Puntarić, I.; Puntarić, E.; Vidosavljević, M.; Muller, A. Analysis and assessment of available water sources in eastern Croatia. Rev. Roum. Chim. 2015, 60, 935-941.

50. Habuda-Stanić, M.; Kuleš, M.; Kalajdžić, B.; Romić, Ž. Quality of groundwater in eastern Croatia. The problem of arsenic pollution. Desalination 2007, 210, 157-162. [CrossRef]

51. Romić, Ž.; Habuda-Stanić, M.; Kalajdžić, B.; Kuleš, M. Arsenic distribution, concentration and speciation in groundwater of the Osijek area, eastern Croatia. Appl. Geochem. 2011, 26, 37-44. [CrossRef]

52. Juračić, M.; Vitturi, L.M.; Rabitti, S.; Rampazzo, G. Suspended matter properties and its role in pollutant transfer from the river to the sea. Case study: Adige river-Adriatic Sea. Sci. Total Environ. 1986, 55, 243-249. [CrossRef]

53. Juračić, M.; Vitturi, L.M.; Rabitti, S.; Rampazzo, G. The role of suspended matter in the biogeochemical cycles in the Adige river estuary (Northern Adriatic Sea). Estuar. Coast. Shelf Sci. 1987, 24, 349-362. [CrossRef]

54. Benfenati, E.; Di Toro, N.; Fanelli, R.; Lualdi, G.; Tridico, R.; Stella, G.; Buscaini, P.; Stimilli, L. Characterization of organic and inorganic pollutants in the Adige river (Italy). Chemosphere 1992, 25, 1665-1674. [CrossRef]

55. Fuganti, A.; Morteani, G.; Bazzoli, G.; Cocco, S.; Santuliana, E.; Visintainer, M. L'arsenico nelle rocce, nelle acque superficiali e nelle acque sotterranee della valle dell' Adige fra Mezzolombardo e Mattarello e presso Roveré della luna (Trento). Atti Acc. Rov. Agiati 2005, 5, 59-94.

56. Duzzin, B.; Pavoni, B.; Donazzolo, R. Macroinvertebrate communities and sediments as pollution indicators for heavy metals in the River Adige (Italy). Water Res. 1988, 22, 1353-1363. [CrossRef]

57. Turgut, C. The contamination with organochlorine pesticides and heavy metals in surface water in Kücük Menderes River in Turkey, 2000-2002. Environ Int 2002, 29, 29-32. [CrossRef] 